\title{
REVIEW
}

\section{Tetrac as an anti-angiogenic agent in cancer}

\author{
Kathrin A Schmohl, Peter J Nelson and Christine Spitzweg \\ Department of Internal Medicine IV, University Hospital of Munich, LMU Munich, Munich, Germany
}

Correspondence should be addressed to C Spitzweg: christine.spitzweg@med.uni-muenchen.de

\begin{abstract}
The thyroid hormones T3 and T4 have emerged as pro-angiogenic hormones with important implications for cancer management. Endogenous circulating hormone levels may help stimulate cancer progression and limit the effectiveness of anticancer therapy, though clinical data remain inconclusive. The capacity of thyroid hormones to modulate angiogenesis is mediated through non-canonical mechanisms initiated at the cell surface receptor integrin $\alpha \vee \beta 3$. This integrin is predominantly expressed on tumour cells, proliferating endothelial cells and tumour stroma-associated cells, emphasising its potential relevance in angiogenesis and tumour biology. Thyroid hormone/integrin $\alpha \vee \beta 3$ signalling results in the activation of intracellular pathways that are commonly associated with angiogenesis and are mediated through classical pro-angiogenic molecules such as vascular endothelial growth factor. The naturally occurring $\mathrm{T} 4$ analogue tetrac blocks the pro-angiogenic actions of thyroid hormones at the integrin receptor, in addition to agonist-independent anti-angiogenic effects. Tetrac reduces endothelial cell proliferation, migration and tube formation through a reduction in the transcription of vascular growth factors/growth factor receptors, hypoxia-inducible factor- $1 \alpha$, pro-angiogenic cytokines and a number of other pro-angiogenic genes, while at the same time stimulating the expression of endogenous angiogenesis inhibitors. It further modulates vascular growth factor activity by disrupting the crosstalk between integrin $\alpha \vee \beta 3$ and adjacent growth factor receptors. Moreover, tetrac disrupts thyroid hormone-stimulated tumour recruitment, differentiation and the pro-angiogenic signalling of tumour stromaassociated mesenchymal stem cells. Tetrac affects tumour-associated angiogenesis via multiple mechanisms and interferes with other cancer cell survival pathways. In conjunction with its low toxicity and high tissue selectivity, tetrac is a promising candidate for clinical application.
\end{abstract}

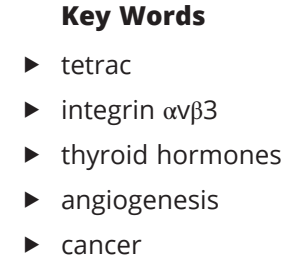

Endocrine-Related Cancer (2019) 26, R287-R304

\section{Introduction}

The thyroid hormones 3,5,3'-triiodo-L-thyronine (T3) and L-thyroxine (T4) are essential regulators of development, differentiation, growth and metabolism, both in the developing and the adult organism (Brent 2012, Davis et al. 2018). Given that they influence such a broad range of processes, it is not surprising that growing clinical and experimental evidence suggests that they are also implicated in cancer development and progression, affecting cancer cell proliferation, cancer cell defence pathways and angiogenesis (Davis et al. 2014b). These effects are thought to be mediated in large part by a non-canonical pathway initiated at the extracellular domain of the plasma membrane protein integrin $\alpha v \beta 3$, first described by Paul Davis and co-workers (Bergh et al. 2005). Integrin $\alpha v \beta 3$ is primarily expressed on cancer cells, dividing endothelial cells and tumour 
stroma-associated cells, thus highlighting its potential importance in oncology (Dijkgraaf et al. 2009, Schmohl et al. 2015). 3,5,3',5'-tetraiodothyroacetic acid (tetrac), a naturally occurring metabolite of $\mathrm{T} 4$, specifically blocks the binding and thyroid hormone action at the integrin receptor (Bergh et al. 2005).

The present review will focus on the role of thyroid hormone signalling via integrin $\alpha v \beta 3$ in tumour angiogenesis with an emphasis on tetrac in its function as angiogenesis inhibitor and discuss the implications for the management of cancer patients.

\section{Thyroid hormones and cancer - clinical data}

The earliest record of a possible relationship between thyroid hormone and cancer was composed by Beatson in 1896 - without knowing about the existence of hormones or what cancer actually was - when he treated breast cancer patients with thyroid extract as 'powerful lymphatic stimulant', noting, however, that 'by itself thyroid extract seems to have little effect on the cancerous process' (Beatson 1896). Since then, numerous studies, clinical and population-based, as well as experimental, have tried to shed light on the potential effects of thyroid hormone on both the risk of developing cancer and its effects on existing tumours. In contrast to Beatson's observations, our current knowledge does suggest a connection between thyroid function and cancer, though there is no consensus on how this occurs and thus, 120 years later, the issue remains controversial (Table 1).

\section{Thyroid hormone status and cancer survival}

Several studies have examined the relationship between cancer survival and alterations in thyroid status. In prostate cancer patients, hyperthyroidism, in this case higher T3 levels, was associated with a higher clinical stage and a higher risk of recurrence (Lehrer et al. 2001). Hypothyroid lung cancer patients, in contrast, had an increased median survival and were older at disease onset (Hercbergs et al. 2010). Furthermore, invasive breast cancer incidence, and incidence of lymph node metastases, were found to be significantly lower with slower progression and smaller, more likely localised tumours in hypothyroid breast cancer patients as compared to euthyroid patients that were more likely to have metastatic disease (Cristofanilli et al. 2005, Hercbergs et al. 2010, Angelousi et al. 2017). However, another study found no relationship between thyroid function and breast cancer survival
(Jiskra et al. 2007). To complicate things further, hypothyroidism was found to be associated with a poorer overall and/or recurrence-free survival in patients with uveal melanoma and hepatocellular carcinoma (Oba et al. 2017, Zhang et al. 2018). Furthermore, low T3 syndrome, characterised by low serum T3 with low or normal free T4 and normal thyroid-stimulating hormone (TSH) levels, was associated with reduced progression-free survival and overall survival in diffuse large B cell lymphoma patients. Patients with synchronously low free T3 and free T4 had a worse outcome than did those with low free T3 alone (Gao et al. 2017). Free T4 levels were also shown to be positively correlated with improved breast cancer survival, while no association was found for free T3 (Brandt et al. 2016).

In addition to cancer mortality in patients with existing cancer, numerous epidemiological studies have tried to correlate the risk of developing cancer and the thyroid state. In this context, again both hyperthyroidism and hypothyroidism have been shown to influence cancer onset in both directions and thus no clear consensus exists. As this goes beyond the scope of the current review, please refer to recent studies and reviews for more information on the subject (Hellevik et al. 2009, Khan et al. 2016, Chan et al. 2017, Ortega-Olvera et al. 2018; reviewed in Hercbergs et al. 2010, Moeller \& Führer 2013).

\section{Thyroid dysfunctions as side effect of cancer treatment}

Further evidence of thyroid hormone involvement in cancer progression has derived from the chance observation that cancer patients that develop hypothyroidism as unwanted side effect of treatment often show a more favourable outcome. In this context, a typical side effect of tyrosine kinase inhibitors is unintended hypothyroidism seen in $36-85 \%$ of patients (Buda-Nowak et al. 2017, Lechner et al. 2018b). This has been described for sunitinib and sorafenib in renal cell carcinoma patients, where a number of studies found a positive correlation of hypothyroidism with progressionfree and/or overall survival compared to euthyroid patients, even with metastatic disease (Riesenbeck et al. 2011, Schmidinger et al. 2011, Baldazzi et al. 2012, Kust et al. 2014, Buda-Nowak et al. 2017). However, in another study, after T4 supplementation of all subclinically and overtly hypothyroid patients with metastatic disease treated with sunitinib, no correlation with survival and no difference between supplemented patients and naturally 
Table 1 Effects of thyroid function on cancer outcomes.

\begin{tabular}{|c|c|c|}
\hline Cancer type & Thyroid function and outcome & References \\
\hline Breast & $\begin{array}{l}\text { Hypothyroidism: slower progression, smaller, more } \\
\text { localised tumours, fewer metastases }\end{array}$ & Cristofanilli et al. (2005) \\
\hline Breast & Hypothyroidism: smaller tumours, lower stage & Hercbergs et al. (2010) \\
\hline Breast & Hypothyroidism: lower incidence of metastases & Angelousi et al. (2017) \\
\hline Breast & $\begin{array}{l}\text { No prognostic significance of free T4 or TSH on relapse- } \\
\text { free and overall survival }\end{array}$ & Jiskra et al. (2007) \\
\hline Breast & Free T4 positively correlated with improved survival & Brandt et al. (2016) \\
\hline Glioma & $\begin{array}{l}\text { Chemically induced hypothyroidism: tumour regression, } \\
\text { prolonged progression-free and overall survival }\end{array}$ & Hercbergs et al. (2003), Ashur-Fabian et al. (2013) \\
\hline Head and neck & $\begin{array}{l}\text { Radiation-induced hypothyroidism: improved recurrence- } \\
\text { free and overall survival }\end{array}$ & Nelson et al. (2006) \\
\hline Hepatoma & $\begin{array}{l}\text { Hypothyroidism: poorer recurrence-free and overall } \\
\text { survival }\end{array}$ & Zhang et al. (2018) \\
\hline Lung & $\begin{array}{l}\text { Amiodarone-induced severe hypothyroidism: patient } \\
\text { entered remission (single case report) }\end{array}$ & Hercbergs \& Leith (1993) \\
\hline Lung & Hypothyroidism: increased median survival & Hercbergs et al. (2010) \\
\hline Lymphoma & $\begin{array}{l}\text { Low T3 syndrome: reduced progression-free and overall } \\
\text { survival; worse outcome when both free T3 and free T4 } \\
\text { were low }\end{array}$ & Gao et al. (2017) \\
\hline Melanoma & $\begin{array}{l}\text { Interleukin-2-induced hypothyroidism: improved } \\
\text { progression-free survival }\end{array}$ & Reid et al. (1991) \\
\hline Prostate & $\begin{array}{l}\text { Hyperthyroidism (high T3): higher clinical stage, higher risk } \\
\text { of recurrence }\end{array}$ & Lehrer et al. (2001) \\
\hline Renal & $\begin{array}{l}\text { Interleukin-2-induced hypothyroidism: higher rate of } \\
\text { remission, improved progression-free survival }\end{array}$ & Reid et al. (1991), Weijl et al. (1993) \\
\hline Renal & $\begin{array}{l}\text { Tyrosine kinase-induced hypothyroidism: increased } \\
\text { progression-free and/or overall survival }\end{array}$ & $\begin{array}{l}\text { Riesenbeck et al. (2011), Schmidinger et al. (2011), } \\
\text { Baldazzi et al. (2012), Kust et al. (2014), Buda- } \\
\text { Nowak et al. (2017) }\end{array}$ \\
\hline Renal & $\begin{array}{l}\text { Tyrosine kinase-induced hypothyroidism: no effect on } \\
\text { progression-free survival under thyroid hormone } \\
\text { supplementation }\end{array}$ & Sabatier et al. (2012) \\
\hline Uveal melanoma & Hypothyroidism: poorer survival & Oba et al. (2017) \\
\hline Diverse & $\begin{array}{l}\text { Induced euthyroid hypothyroxinaemia (low T4, normal T3): } \\
\text { prolongation of survival in advanced cancers }\end{array}$ & Hercbergs et al. (2015) \\
\hline Diverse & $\begin{array}{l}\text { Tyrosine kinase-induced hypothyroidism: improved overall } \\
\text { survival }\end{array}$ & Lechner et al. $(2018 a, b)$ \\
\hline
\end{tabular}

TSH, thyroid-stimulating hormone.

euthyroid patients was found (Sabatier et al. 2012). This suggested that thyroid hormone replacement may reduce the survival benefits gained from hypothyroidism (Sabatier et al. 2012). A recent retrospective study in patients with advanced non-thyroidal tumours of different entities has confirmed an overall survival benefit for those patients that developed hypothyroidism after tyrosine kinase inhibitor therapy. Here, however, thyroid hormone replacement therapy further improved overall survival as compared to those that did not receive replacement therapy (Lechner et al. 2018a).

Similarly, in a retrospective analysis of patients with head and neck squamous cell cancer, patients that developed hypothyroidism from radiation treatment had a significantly lower risk of death or recurrence (Nelson et al. 2006).
Studies from the 1990s using interleukin-2 treatment against renal cell cancer and malignant melanoma that can cause thyroiditis with subsequent hypothyroidism in some patients found less risk of death from progressive disease under hypothyroidism and partial/complete remission in the majority of hypothyroid patients (Reid et al. 1991, Weijl et al. 1993).

In a single case report, treatment of a patient with metastatic non-small cell lung cancer with amiodarone $\mathrm{HCl}$ for cardiac arythmia caused severe amiodarone-induced hypothyroidism (myxoedema coma) with extremely low T4. The patient entered clinical remission, an extremely rare event in lung cancer, coincident with the severe thyroid hormone deficiency. Though the patient subsequently received thyroxine supplementation, no disease recurrence or progression was documented (Hercbergs \& Leith 1993). 


\section{Induced hypothyroidism for cancer treatment}

In syngeneic and xenograft rodent models of breast, liver, lung and prostate cancer, sarcoma and fibrosarcoma, the induction of hypothyroidism - induced chemically, by radioiodine ablation or by surgical thyroidectomy - led to a reduction in tumour growth in all models studied as compared to untreated controls (Shoemaker et al. 1976, Kumar et al. 1979, Mishkin et al. 1981, Theodossiou et al. 1999, Theodossiou \& Schwarzenberger 2000, MartinezIglesias et al. 2009, Moeller \& Führer 2013). Based on these findings, hypothyroidism has been deliberately induced in cancer patients in a few pioneering studies. And indeed, propylthiouracil (PTU)-induced mild hypothyroidism in glioma patients, including grade IV astrocytoma, was associated with tumour regression and a statistically significant prolongation of survival and time-to-progression (Hercbergs et al. 2003, 2010). Likewise, after failing first-line standard treatment, a patient with inoperable grade IV glioblastoma multiforma of the optic chiasm was treated with PTU and thioamide to chemically induce hypothyroidism in conjunction with carboplatin chemotherapy leading to successful long-term tumour response, and prolonged overall survival (Ashur-Fabian et al. 2013). Interestingly, pharmacologic induction of a euthyroid hypothyroxinemic state under maintenance of normal circulating T3 levels and euthyroidism with substantial reduction of circulating $\mathrm{T} 4$ levels in advanced cancer patients with brain, ovary, lung, pancreas and salivary gland tumours, mesothelioma and soft-tissue sarcoma was associated with a significant prolongation of actual versus expected survival (Hercbergs et al. 2015).

Identifying an association between thyroid function and cancer progression or cancer risk is not straightforward, which probably underlies the high variance in study outcomes reported. For one, causality cannot be easily inferred, that is thyroid hormone and/or TSH levels, often used as sole indicator of thyroid function, may be influenced by the cancer itself and not necessarily vice versa (Brandt et al. 2016, Chan et al. 2017). Further, other co-morbidities and lifestyle choices may affect both thyroid function and cancer progression at the same time. Age, obesity, hypertension, diabetes, smoking, alcohol consumption and dyslipidaemia have been associated with cancer mortality and incidence, and have been reported to alter thyroid hormone and/or TSH levels (Belin et al. 2004, Jorde \& Sundsfjord 2006, Asvold et al. 2007, Mehran et al. 2012, Yeap et al. 2012, Tseng et al. 2015). In the case of sex hormone-dependent cancers, such as breast, ovarian and prostate cancer, changes in thyroid hormone concentrations may affect circulating sex hormone concentrations with different effects on tumour subtypes depending on receptor status (Saraiva et al. 2005, Chan et al. 2017). In this context, the menopausal status of women is a further critical factor. Not all studies are corrected for these confounders. Variation in inclusion criteria, for example whether subclinical thyroid hormone disorders or patients on thyroid-related medications were included, as well as which and how often thyroid metabolites were measured to determine thyroid function, further confound comparability. In addition, studies are often based on small case numbers and consequently lack sufficient statistical power to reliably assess potential associations between thyroid function and cancer. At the level of the tumour itself, the ability to react to thyroid hormone depends on the expression of different receptors (see below). Furthermore, the local, tissue-specific thyroid hormone status in the tumour environment may differ from the systemic status. A local hypothyroid state in the liver has, for instance, been proposed to drive hepatocellular carcinoma development and progression (Perra et al. 2016).

In conclusion, a lot of effort has been put into the study of the role of thyroid hormones both in the aetiology and progression of cancer. So far, data from clinical and epidemiological studies remain highly inconsistent. Identifying those cancer patients that would profit from manipulation of their thyroid hormone levels remains an important open question.

\section{Thyroid hormone signalling}

The main secretory product of the thyroid gland is $\mathrm{T} 4$. Conversion to T3, conventionally acknowledged as the bioactive iodothyronine, occurs mainly in peripheral tissues by deiodinases. Canonical thyroid hormone effects are then exerted through binding of $\mathrm{T} 3$ to thyroid hormone receptor (TR) isoforms that are localised in the nucleus and act as ligand-dependent transcription factors (Cheng et al. 2010, Moeller \& Führer 2013). In this 'classical' or 'genomic' pathway, T4 functions as pro-hormone for T3, as most of the thyroid hormone bound to TRs is T3 (Sinha \& Yen 2000, Brent 2012). Besides effects involving T3 binding to nuclear hormone receptors, several so-called 'non-genomic' pathways have been identified, where initiation occurs in the cytoplasm, the mitochondria, or, as in the focus of this review, at the plasma membrane (Davis et al. 2018). (c) 2019 Society for Endocrinology Published by Bioscientifica Ltd. Printed in Great Britain 


\section{Cell surface signalling}

An early indicator of the potential existence of a membrane-based TR was the observation that ${ }^{131}$ I-labelled $\mathrm{T} 3$ and T4 bind to the cell membrane of enucleated erythrocytes, providing the basis for an in vitro method to measure free hormone concentrations in patients and thus evaluate their thyroid function (Freedberg et al. 1957, Hamolsky et al. 1959, Schwartz et al. 1968). In an attempt to elucidate the molecular structure essential for binding of thyroid hormone to membranes, Singh et al. observed that the T4 derivative tetrac displaces ${ }^{131} \mathrm{I}-\mathrm{T} 3$ and 131I-T4 from the membrane (Singh et al. 1976). That the binding site may function as a hormone receptor in the intact cell became apparent when ion pumps such as the $\mathrm{Ca}^{2+}$ ATPase were found to be rapidly activated by thyroid hormone, both in enucleated and nucleated cells, via activation of protein kinase signal transduction pathways (reviewed in Lin et al. 2012, Davis et al. 2018). Subsequently, both T3 and T4 were found to effectively activate the mitogen-activated protein kinase (MAPK; extracellular signal-regulated kinases $1 / 2$ (ERK1/2)) pathway in cells that lack TR expression. T4 bound to an agarose bead, restricting it to the extracellular space, reproduced this effect, demonstrating that it had to be plasma membrane-initiated. Tetrac, in contrast, inhibited the kinase activation (Lin et al. 1999a). Despite growing evidence for the existence of a cell surface TR, it was not until 2005 that Paul Davis' laboratory identified the elusive receptor as integrin $\alpha v \beta 3$ (Bergh et al. 2005).

\section{Thyroid hormone receptor on integrin $\alpha \mathrm{v} \beta 3$}

Integrins are heterodimeric cell surface receptors involved in cell-cell and cell-extracellular matrix protein interactions, and have emerged as major regulators of the activity of various cell signalling pathways. Though integrins themselves are not oncogenic, their expression by tumour and tumour stroma-associated cells critically contributes to tumour progression and metastasis (Desgrosellier \& Cheresh 2010). Ligand-binding to the extracellular domain is translated into downstream signalling events via outside-in signalling inside the cell, usually engaging signal-transducing kinase cascades (Xiong et al. 2001). Integrin signalling is typically transduced into cell motility, adhesion, division and angiogenesis via direct effects on the cytoskeleton and modulation of gene transcription. Furthermore, crosstalk between integrins and neighbouring growth factor and cytokine receptors, affecting their expression, ligand affinity and signalling, seems to be required for many of their tumour-promoting effects (Desgrosellier \& Cheresh 2010).

That the integrin $\alpha v \beta 3$ is a mediator of tumourrelated angiogenesis is now a well-established concept that was first described in the 1990s (Brooks et al. 1994). Tumour-associated vessels, unlike quiescent endothelium, express the integrin, and its expression on tumour cells is correlated with disease progression (Desgrosellier \& Cheresh 2010). Its prototypic ligand is the extracellular matrix glycoprotein vitronectin that binds to the integrin's extracellular domain via an RGD (arginine-glycineaspartic acid) sequence (Ruoslahti \& Pierschbacher 1987). The thyroid hormone-binding site on integrin $\alpha v \beta 3$ is located near this RGD recognition site and comprises two distinct domains that are related neither structurally nor functionally to TRs (Cody et al. 2007, Lin et al. 2009). The binding site $\mathrm{S} 1$ exclusively binds $\mathrm{T} 3$ and causes activation of the phosphoinositide 3-kinase (PI3K) cascade, while S2 binds both T3 and T4 and results in MAPK (ERK1/2) pathway activation (Lin et al. 2009). Thus, in contrast to the TR/thyroid hormone axis, both T4 and T3 act as active hormones at the integrin receptor. In fact, as the affinity for T4 is far higher than that for T3, and lies in the physiologic concentration range that is comparable to the T3 affinity for nuclear receptors, T4 may well be the main hormone signalling at the integrin, thus transcending its role of pro-hormone for T3 (Davis et al. 2013b). Tetrac binds to both thyroid hormone-binding sites on the integrin and is a specific inhibitor of integrin-mediated thyroid hormone action (Wu et al. 2005, Mousa et al. 2006). Within the cell, in contrast, tetrac has low-grade thyromimetic activity, both by itself, as well as through its conversion to triiodothyroacetic acid (triac) (Burger et al. 1979, Moreno et al. 2008). By covalently binding tetrac to an approximately $200 \mathrm{~nm}$, biodegradable nanoparticle (Nanotetrac), it is excluded from the cell interior and thus acts exclusively at the integrin (Yalcin et al. 2009). The genes that are modulated from the extracellular domain of integrin $\alpha \mathrm{v} \beta 3$ by thyroid hormone relate to cancer cell proliferation, apoptosis, chemo/radioresistance and angiogenesis (Davis et al. 2014a).

\section{Thyroid hormones and angiogenesis}

Angiogenesis, the formation of new blood vessels from the existing vasculature, is a highly regulated process, temporally and spatially controlled by a balance between pro- and anti-angiogenic factors (Pinto et al. 2011, (c) 2019 Society for Endocrinology Published by Bioscientifica Ltd. Printed in Great Britain 
Bronckaers et al. 2014). In response to specific stimuli, including hypoxia and inflammation, the angiogenic switch occurs in the quiescent endothelium, initiating coordinated endothelial cell proliferation, invasion, migration and ultimately, tube formation and maturation. Angiogenesis is closely linked to tumour progression, both sustaining tumour growth by providing oxygen and other nutrients, and facilitating metastasis. While physiological angiogenesis in the context of development, tissue growth and wound-healing is tightly regulated and self-limiting, cancer-associated angiogenesis, though in principle regulated by the same pathways, is usually persistent and abnormal (Avraamides et al. 2008).

Angiogenesis is orchestrated by local release of vascular growth factors and their discrete receptors on the cell surface that then transduce specific signals into angiogenesis-related events. The vascular endothelial growth factor (VEGF) is the archetypal stimulator of angiogenesis, both under normal physiologic conditions and in the tumour environment. VEGF initiates the angiogenic process by activating endothelial cells, fostering their migration and proliferation, and mediating vascular permeability (Somanath et al. 2009). Other major pro-angiogenic vascular growth factors include fibroblast growth factor 2 (FGF2, also known as basic fibroblast growth factor; bFGF), platelet-derived growth factor (PDGF) and the angiopoietins. The angiogenic process is additionally supported by contributions from less specific factors, such as the epidermal growth factor (EGF), transforming growth factors (TGF)- $\alpha$ and $-\beta$, and cytokines such as interleukins -1 (IL-1), -6 (IL-6) and -8 (IL-8) and their respective receptors. Endogenous inhibitors of angiogenesis include thrombospondin 1, angiostatin and endostatin (Avraamides et al. 2008, Bronckaers et al. 2014). These angiogenesis-relevant factors are produced by tumour cells, the endothelial cells themselves and by cells of the tumour stroma such as cancer-associated fibroblasts, pericytes and infiltrating immune cells (Ellis 2004, Bronckaers et al. 2014).

\section{Discovery of the pro-angiogenic nature of thyroid hormones}

Chilian et al. made the initial observation of a proangiogenic effect of thyroid hormones when they discovered that induction of myocardial hypertrophy in the rat by thyroxine leads to a higher capillary density before hypertrophy sets in, that is that angiogenesis is not driven by tissue enlargement of the heart per se (Chilian et al. 1985, Tomanek \& Busch 1998).
However, it took another two decades until the underlying mechanisms were systematically addressed using the chick chorioallantoic membrane (CAM) angiogenesis model, not only establishing that iodothyronines are angiogenesis modulators, but also leading to the discovery of the thyroid hormone receptor on integrin $\alpha v \beta 3$. The group around Paul Davis could show that (1) both T3 and $\mathrm{T} 4$ are pro-angiogenic, $\mathrm{T} 4$ at physiological levels and to a greater extent; (2) the blocking of conversion of T4 to T3 with the deiodinase inhibitor PTU did not abrogate the pro-angiogenic effect of T4; (3) agarose-linked T4 reproduced the angiogenic effects; (4) while tetrac alone had no effect on angiogenesis, it did block the effects of T4 and T4-agarose; (5) the addition of an antibody against FGF2 abrogated angiogenesis stimulated by T4, suggesting that, at least in part, the pro-angiogenic effect of T4 is mediated by increased FGF2 expression; and (6) inhibition of the MAPK (ERK1/2) pathway completely blocked pro-angiogenic thyroid hormone action. They could further show that T4 could rapidly (within $6 \mathrm{~h}$ ) induce FGF2 mRNA expression in endothelial cells and that both T3 and T4 were able to foster FGF2 secretion from endothelial cells in a MAPK (ERK1/2)-dependent manner (Davis et al. 2004).

Iodothyronines have since emerged as non-classical pro-angiogenic modulators that induce neovascularisation via integrin $\alpha v \beta 3$-based pathways in a variety of settings, including the heart, ischaemic striated muscle and the tumour microenvironment (Luidens et al. 2010). Acting at integrin $\alpha v \beta 3$, tetrac antagonises stimulation of angiogenesis by thyroid hormone (Table 2).

\section{Inhibition of pro-angiogenic thyroid hormone effects by tetrac}

Tetrac was shown to inhibit the potentiation by T4 of EGFand TGF- $\alpha$-induced signal transduction via MAPK (ERK1/2) in HeLa cells that lack nuclear TRs (Lin et al. 1999b, Shih et al. 2004). Both EGF and TGF- $\alpha$ are EGF receptor (EGFR) ligands that are known to induce VEGF expression (Ellis 2004). Similarly, phosphorylation of protein kinase D and phosphorylation and cytoplasmic accumulation of histone deacetylase 5, implicated in regulation of gene transcription and angiogenesis downstream of VEGF signalling, were stimulated by $\mathrm{T} 4$, leading to increased FGF2 expression and decreased by additional treatment with tetrac in endothelial cells (Ha et al. 2008, Liu et al. 2014). Furthermore, thyroid hormone-enhanced matrix metalloproteinase 9 transcription and activity were subject to inhibition by tetrac, as was the activity of PDGF 
Table 2 Angiogenesis-relevant targets of thyroid hormones and tetrac.

\begin{tabular}{ll}
\hline Target & Effect \\
\hline Tube formation & $\uparrow \mathrm{T} 3, \mathrm{~T} 4$ \\
& $\downarrow$ tetrac \\
Endothelial cell migration & $\uparrow \mathrm{T} 3, \mathrm{~T} 4$ \\
& $\downarrow$ tetrac \\
Endothelial cell proliferation & $\uparrow \mathrm{T} 3, \mathrm{~T} 4$ \\
& $\downarrow$ tetrac \\
FGF2 expression and secretion & $\uparrow \mathrm{T} 3, \mathrm{~T} 4$ \\
& $\downarrow$ tetrac \\
VEGF expression & $\uparrow \mathrm{T} 3, \mathrm{~T} 4$ \\
& $\downarrow$ tetrac \\
Angiopoietin-1 expression & $\uparrow \mathrm{T} 3, \mathrm{~T} 4$ \\
& $\downarrow$ tetrac \\
MMP9 expression and activation & $\uparrow \mathrm{T} 3, \mathrm{~T} 4$ \\
& $\downarrow$ tetrac \\
HIF-1 $\alpha$ transcription & $\uparrow \mathrm{T} 4$ \\
& $\downarrow$ tetrac* \\
EGF- and TGF- $\alpha$-induced pro-angiogenic & $\uparrow \mathrm{T} 4$ \\
signalling & $\downarrow$ tetrac \\
Pericyte marker expression & $\uparrow \mathrm{T} 3, \mathrm{~T} 4$ \\
& $\downarrow$ tetrac \\
Pro-angiogenic (growth) factor expression & $\uparrow \mathrm{T} 3, \mathrm{~T} 4$ \\
and secretion & $\downarrow$ tetrac \\
Hypoxia response and VEGF signalling & $\uparrow \mathrm{T} 3, \mathrm{~T} 4$ \\
& $\downarrow$ tetrac \\
Tumour recruitment of angiogenesis- & $\uparrow \mathrm{T} 3, \mathrm{~T} 4$ \\
promoting cells & $\downarrow$ tetrac \\
\hline
\end{tabular}

\begin{tabular}{l}
\hline Model \\
\hline Endothelial cells, CAM \\
Endothelial cells \\
Endothelial cells \\
Endothelial cells, CAM \\
Endothelial cells \\
Endothelial cells \\
Cancer cells (multiple \\
myeloma) \\
Cancer cells (lung and \\
ovarian) \\
Cancer cells (cervical) \\
Mesenchymal stem cells/ \\
hepatoma \\
Mesenchymal stem cells/ \\
hepatoma \\
Mesenchymal stem cells/ \\
hepatoma \\
Mesenchymal stem cells/ \\
hepatoma
\end{tabular}

\begin{tabular}{l}
\hline References \\
\hline $\begin{array}{l}\text { Mousa et al. (2006, 2008), Balzan et al. } \\
\text { (2013), Liu et al. (2014) } \\
\text { Balzan et al. (2013), Liu et al. (2014) } \\
\text { Balzan et al. (2013) } \\
\text { Davis et al. (2004), Liu et al. (2014) } \\
\text { Balzan et al. (2013) } \\
\text { Balzan et al. (2013) } \\
\text { Cohen et al. (2014) } \\
\text { Lin et al. (2013), Davis et al. (2015) } \\
\text { Shih et al. (2004) } \\
\text { Schmohl et al. (2015) } \\
\text { Schmohl et al. (2015), Schmohl et al. } \\
\text { unpublished observations** } \\
\text { Schmohl et al. unpublished } \\
\text { observations** } \\
\text { Schmohl et al. (2015) }\end{array}$
\end{tabular}

*proposed effect. **Schmohl KA, Mueller AM, Dohmann M, Spellerberg R, Urnauer S, Schwenk N, Ziegler SI, Nelson PJ \& Spitzweg C, unpublished observations.

CAM: chorioallantoic membrane; EGF: epidermal growth factor; FGF2: fibroblast growth factor 2; HIF-1 $\alpha$ : hypoxia-inducible factor 1 $\alpha$; MMP9: matrix metalloproteinase 9; TGF- $\alpha$ : transforming growth factor $\alpha$; VEGF: vascular endothelial growth factor.

(Cohen et al. 2014, Davis et al. 2014b). Matrix metalloproteinases promote angiogenesis by preparing the vascular bed, that is facilitating endothelial cell detachment and paving the way for the advancing vascular sprout, and through sequestration and activation of angiogenic mediators such as VEGF from the extracellular matrix (Davis et al. 2015, Deryugina \& Quigley 2015). In addition, thyroid hormone stimulates endothelial cell proliferation, migration and vascular tube formation, all important prerequisites for angiogenesis - activities shown to be inhibited by tetrac (Mousa et al. 2006, Balzan et al. 2013, Liu et al. 2014, Mousa et al. 2014).

\section{Effects on the hypoxia response}

Hypoxia, that is low oxygen tension, occurs in rapidly growing and progressively more poorly vascularised tumours. This leads to increased expression and stabilisation of hypoxia-inducible factor- $1 \alpha$ (HIF- $1 \alpha)$ and subsequent heterodimerisation with HIF-1 $\beta$ to form HIF-1. This master regulator of the adaptive response of tissues to hypoxia fosters the transcription of a host of genes relevant to tumour progression and angiogenesis, including VEGF (Liu et al. 2009, Semenza 2010). HIF-1 $\alpha$ transcription is sensitive to thyroid hormone: As shown in human nonsmall cell lung cancer and ovarian carcinoma cells, T4, but not T3, induces internalisation of integrin $\alpha v \beta 3$, resulting in a complex formed between the $\alpha \mathrm{V}$ monomer and MAPK (ERK1/2), leading to nuclear import (Lin et al. 2013). In the nucleus, $\alpha \mathrm{v}$ acts as a transcriptional co-activator and helps to drive the transcription of HIF- $1 \alpha$. Tetrac and Nanotetrac inhibit integrin internalisation, and thus, can block this angiogenic effect of thyroid hormone (Lin et al. 2011, Davis et al. 2014a, 2015). Interestingly, the $\alpha \mathrm{v}$ gene (ITGAV) itself, in turn, contains hypoxia response elements in its promoter region and is hence a HIF-1 target gene (Nieberler et al. 2017). The HIF-1 $\alpha$-related pro-angiogenic activity of thyroid hormone is thought to be especially relevant in the context of a hypoxic tumour setting. Furthermore, T3 has been reported to induce HIF-1 $\alpha$ expression by a PI3K-dependent mechanism (Moeller et al. 2005, Moeller et al. 2006). Whether this effect is initiated at a cytoplasmically located TR, or at the cell surface at integrin $\alpha v \beta 3$, or both, remains to be elucidated (Luidens et al. 2010). (c) 2019 Society for Endocrinology Published by Bioscientifica Ltd. Printed in Great Britain 
Thus, tetrac, functioning as a thyroid hormone antagonist at integrin $\alpha v \beta 3$, interferes with numerous pro-angiogenic activities of thyroid hormones, which ultimately leads to decreased vessel formation.

\section{Agonist-independent effects of tetrac on angiogenesis}

Tetrac was initially thought to exert its anti-angiogenic actions only by disrupting interaction of thyroid hormone with the integrin receptor. However, it was subsequently found to block the pro-angiogenic activity of VEGF and FGF2 in the absence of agonist hormone (Table 3).

\section{Effects on transcription and activity of vascular growth factors and their receptors}

Quantitative real-time PCR and microarray studies in different human cancer cells in vitro have confirmed antiangiogenic effects of tetrac on gene transcription: Tetrac and Nanotetrac were shown to significantly decrease the transcription of pro-angiogenic VEGF in human medullary thyroid cancer cells (Yalcin et al. 2010b). Nanotetrac, but not unmodified tetrac, decreased the transcription of EGFR in human breast cancer and pancreatic carcinoma cells (Glinskii et al. 2009, Yalcin et al. 2013). This observation is significant in that the abundance and activity of EGFR is abnormally elevated in most solid tumours and is

Table 3 Agonist thyroid hormone-independent angiogenesis-relevant targets of tetrac and Nanotetrac.

\begin{tabular}{|c|c|c|}
\hline Target & Effect & Model \\
\hline Tube formation & $\downarrow$ tetrac & Endothelial cells \\
\hline Endothelial cell migration & $\downarrow$ tetrac & Endothelial cells \\
\hline Endothelial cell proliferation & $\downarrow$ tetrac & Endothelial cells \\
\hline VEGF-induced angiogenesis & $\downarrow$ tetrac & CAM \\
\hline FGF2-induced angiogenesis & $\begin{array}{l}\downarrow \text { tetrac } \\
\downarrow \text { Nanotetrac }\end{array}$ & CAM, mouse Matrigel plug assay \\
\hline VEGF transcription & $\begin{array}{l}\downarrow \text { tetrac } \\
\downarrow \text { Nanotetrac }\end{array}$ & Cancer cells (thyroid) \\
\hline EGFR transcription & $\downarrow$ Nanotetrac & Cancer cells (breast and pancreas) \\
\hline $\begin{array}{l}\text { Angiopoietin-like 1, } 2 \text { and } 3 \\
\text { transcription }\end{array}$ & $\downarrow$ tetrac & Endothelial cells \\
\hline MMP15, 19 and 24 transcription & $\downarrow$ tetrac & Endothelial cells \\
\hline MMP inhibitor TIMP3 levels & $\uparrow$ tetrac & Endothelial cells \\
\hline $\begin{array}{l}\text { Pro-angiogenic cytokine and } \\
\text { receptor transcription }\end{array}$ & $\downarrow$ Nanotetrac & Cancer cells (breast and thyroid) \\
\hline $\begin{array}{l}\text { Angiostatic cytokine CXCL10 } \\
\text { transcription }\end{array}$ & $\uparrow$ Nanotetrac & Cancer cells (breast and thyroid) \\
\hline Angiopoietin-2 levels & $\downarrow$ tetrac & Endothelial cells \\
\hline MMP9 transcription and activity & $\downarrow$ tetrac & Cancer cells (multiple myeloma) \\
\hline Thrombospondin 1 transcription & $\begin{array}{l}\uparrow \text { tetrac } \\
\uparrow \text { Nanotetrac }\end{array}$ & $\begin{array}{l}\text { Cancer cells (breast, oral, pancreas, } \\
\text { thyroid) }\end{array}$ \\
\hline $\begin{array}{l}\text { Vascular growth factor activity via } \\
\text { receptor crosstalk inhibition }\end{array}$ & $\downarrow$ tetrac & Diverse \\
\hline $\begin{array}{l}\text { Pro-angiogenic activity of LPS, } \\
\text { bradykinin and angiotensin }\end{array}$ & $\downarrow$ Nanotetrac & CAM \\
\hline Pro-angiogenic miR-21 levels & $\downarrow$ Nanotetrac & Cancer cells (breast) \\
\hline Angiostatic miR-15A levels & $\uparrow$ Nanotetrac & Cancer cells (breast) \\
\hline Tumoural haemoglobin content & $\begin{array}{l}\downarrow \text { tetrac } \\
\downarrow \text { Nanotetrac }\end{array}$ & $\begin{array}{l}\text { Cancer cell xenografts in mice } \\
\text { (glioblastoma, lung, pancreas, } \\
\text { renal, thyroid) }\end{array}$ \\
\hline $\begin{array}{l}\text { Tumoural haemoglobin content } \\
\text { and VEGF levels }\end{array}$ & $\downarrow$ tetrac & Murine Lewis lung carcinoma \\
\hline Tumour vascularity & $\downarrow$ Nanotetrac & $\begin{array}{l}\text { Cancer cell xenografts in mice } \\
\text { (glioblastoma) }\end{array}$ \\
\hline Tumoural NF-кB activity & $\downarrow$ Nanotetrac & $\begin{array}{l}\text { Cancer cell xenografts in mice } \\
\text { (urinary bladder) }\end{array}$ \\
\hline
\end{tabular}

References

Mousa et al. (2008), Yoshida et al. (2012), Balzan et al. (2013)

Yoshida et al. (2012)

Yoshida et al. (2012), Balzan et al. (2013)

Mousa et al. (2008)

Mousa et al. (2008), Bharali et al. (2013)

Yalcin et al. (2010b)

Glinskii et al. (2009), Yalcin et al. (2013)

Mousa et al. (2008)

Mousa et al. (2008)

Mousa et al. (2008)

Davis et al. (2013a, 2016)

Davis et al. (2013a, 2016)

Mousa et al. (2008)

Cohen et al. (2014)

Glinskii et al. (2009), Yalcin et al.

(2010b, 2013), Lin et al. (2018)

Davis et al. (2013b, 2015), Incerpi et al. (2014)

Mousa et al. (2014)

Davis et al. (2014b)

Davis et al. (2014b)

Yalcin et al. (2009, 2010a,b, 2013),

Mousa et al. (2012)

Carmona-Cortes et al. (2014)

Sudha et al. (2017a)

Sudha et al. (2017b)

CAM, chorioallantoic membrane; EGFR, epidermal growth factor receptor; FGF2, fibroblast growth factor 2; LPS, lipopolysaccharide; miR, microRNA; MMP, matrix metalloproteinase; NF-кB, nuclear factor kappa B; TIMP3, tissue inhibitor of metalloproteinase 3; VEGF, vascular endothelial growth factor.

https://erc.bioscientifica.com

https://doi.org/10.1530/ERC-19-0058 (c) 2019 Society for Endocrinology Published by Bioscientifica Ltd. Printed in Great Britain 
associated with cancer progression and poor prognosis. Though not a specific angiogenesis-related growth factor, stimulation or inhibition of EGFR has been shown to have significant consequences for tumour angiogenesis (van Cruijsen et al. 2005).

In addition to the direct effects on vascular growth factor/vascular growth factor receptor gene transcription, tetrac was also found to modulate their activity. In detail, tetrac was shown to block VEGF-induced human dermal microvascular endothelial cell tube formation in vitro and the pro-angiogenic activity of FGF2, VEGF and T3 in the CAM assay (Mousa et al. 2008). While unmodified tetrac inhibited FGF2-induced angiogenesis by $60 \%$, nanoparticulate tetrac achieved a near-complete inhibition in the CAM assay (Bharali et al. 2013). In a subcutaneous mouse Matrigel plug assay, tetrac treatment resulted in a significant inhibition of FGF2-induced angiogenesis, as measured by haemoglobin content (Mousa et al. 2008). In human retinal endothelial cells, tetrac was reported to decrease VEGF- and erythropoietintriggered proliferation, inhibit both basal and VEGFinduced migration, and VEGF-induced tube formation in vitro (Yoshida et al. 2012). Similarly, Balzan et al. reported that tetrac at high concentrations $(5 \mu \mathrm{M})$ inhibited basal and VEGF-induced human cardiac microvascular endothelial cell proliferation and tube formation. In a wound-healing assay, tetrac did not influence basal cell migration, but did inhibit enhanced migration by VEGF (Balzan et al. 2013). Tetrac has further been shown to block the pro-angiogenic activities of EGFR and PDGFR, and is hypothesised to inhibit the actions of the insulinlike growth factor 1 receptor (Davis et al. 2013c, 2015, Incerpi et al. 2014).

The basis for the ability of tetrac to disrupt vascular growth factor signalling has been hypothesised to lie in non-transcriptional modulation of the function of vascular growth factor receptors adjacent to $\alpha \mathrm{v} \beta 3$, by interrupting crosstalk between the integrin and growth factor receptors (Davis et al. 2015). Activation of intracellular signalling cascades in endothelial cells by growth factors is amplified when the cells are attached to the extracellular matrix, indicating a synergy between integrin and growth factor signalling. Indeed, integrin $\alpha v \beta 3$ co-clusters and directly interacts with VEGFR, FGFR and PDGFR (Somanath et al. 2009). Disruption of the interaction between integrin $\alpha v \beta 3$ and VEGFR or FGFR results in diminished activation by their respective ligands and impairs integrin activation (Somanath et al. 2009). The RGD recognition pocket plays an essential role in facilitating interactions of the integrin with extracellular matrix proteins, and pro-angiogenic activities of VEGF and FGF2 are blocked by RGD peptides (Yalcin et al. 2009). Tetrac binds to the integrin near the RGD recognition site and may either directly occlude the binding sites for vascular growth factors or lead to conformational changes in the highly plastic integrin, resulting in allosteric inhibition of interaction with vascular growth factors/receptors at the RGD site (Mousa et al. 2008).

Thus, depending on the growth factor, the biologic actions of tetrac can involve gene transcription, growth factor release or inhibitory crosstalk between the integrin and vascular growth factor receptors clustered with the integrin in the plasma membrane.

\section{Effects on cytokines and their receptors}

In addition to vascular growth factors, a number of angiogenesis-relevant interleukins as well as chemokines and their receptors are subject to transcriptional modulation by tetrac in human cancer cell lines. Nanotetrac was shown to reduce the abundance of IL- $1 \alpha$ and $\beta$ mRNA in human breast cancer cells, as determined by microarray gene expression profiling (Davis et al. 2013a). The IL-1 family has been shown to interact with VEGF to initiate and maintain tumour angiogenesis (Voronov et al. 2014). IL-6, a stimulator of a plethora of pro-angiogenic molecules, including VEGF, FGF2 and HIF- $1 \alpha$, and of endothelial cell migration and proliferation, can also be downregulated by Nanotetrac treatment (Davis et al. 2013a, Middleton et al. 2014). By contrast, the expression of IL-11, a member of the IL- 6 family of interleukins, was shown to be increased (Davis et al. 2013a). Though not as conclusively explored as IL-6, IL-11 has been shown to protect microvascular endothelium from inflammation and injury, and to act as a growth factor for haematopoietic stem cells and megakaryocyte progenitor cells (Kirkiles-Smith et al. 2004, Hercbergs et al. 2012, Johnstone et al. 2015). To what extent these observations influence tumour angiogenesis remains to be elucidated.

Nanotetrac was further shown by microarray analysis to decrease the steady-state mRNA levels of the chemokines CCL20, CXCL2, CXCL3 and CX3CL1 in human breast and thyroid cancer cells in a highly correlated pattern (Davis et al. 2013a, 2016). All of these chemokines have been shown to be pro-angiogenic in diverse contexts, including cancer angiogenesis (Mehrad et al. 2007, Ryu et al. 2008, Keeley et al. 2010, Owen \& Mohamadzadeh 2013, Li et al. 2016). CXCL10 transcription, in contrast, is stimulated by Nanotetrac in both cell lines (Davis et al. 2013a, 2016). 
As CXCL10 has angiostatic properties via its receptor CXCR3, this observation fits with the overall anti-angiogenic effects of Nanotetrac at the integrin (Mehrad et al. 2007, Raman et al. 2011). Further, the chemokine receptor genes CCR1, CXCR4 and CX3CR4 are transcriptionally modulated by treatment with Nanotetrac. Transcription of CCR1 was shown to be downregulated by Nanotetrac in breast cancer cells and, in contrast, slightly upregulated in thyroid cancer cells (Davis et al. 2016). CCR1 via its ligands CCL3 and CCL5/RANTES is generally thought to be proangiogenic, by both directly inducing tumour angiogenesis and initiating infiltration of pro-angiogenic macrophages (Marone \& Granata 2014). Surprisingly, the transcription of CXCR4 was increased by Nanotetrac (Davis et al. 2016). Its principal ligand is CXCL12 and CXCL12/CXCR4 signalling is known to stimulate tumour angiogenesis (Meng et al. 2018). Furthermore, transcription of CX3CR1 is decreased by Nanotetrac (Davis et al. 2016). As detailed above, transcription of its ligand CX3CL1 is also affected by Nanotetrac. CX3CL1/CX3CR1 signalling induces angiogenesis via multiple pathways, including effects on HIF- $1 \alpha$ and VEGF, and is thought to be important for the structural integrity of vessels (Owen \& Mohamadzadeh 2013, Szukiewicz et al. 2013). Interestingly, this ligand/ receptor pair is proposed to form a ternary complex with integrin $\alpha v \beta 3$, which leads to activation of the integrin (Goda et al. 2000, Davis et al. 2016). The integrin can also be directly, that is CX3CR1-independently, activated by CX3CL1 by its binding to a site near the TR on the integrin (Fujita et al. 2014, Davis et al. 2016). This close proximity suggests that the binding sites may interact and CX3CL1 binding may be influenced by thyroid hormone and tetrac (Davis et al. 2016). Moreover, as CX3CL1 is known to undergo cell internalisation and thyroid hormone has been shown to drive internalisation of integrin $\alpha v \beta 3$, Davis et al. have hypothesised that cellular uptake of CX3CL1 may be modulated by thyroid hormone binding to its site on the integrin (Lin et al. 2013, Davis et al. 2016). This interference of tetrac with the transcription of chemokine/chemokine receptor genes constitutes an important aspect of its antitumour activity. Aside from angiogenesis, chemokine signalling is also fundamental for intra- and intercellular communication in the tumour microenvironment.

\section{Effects on transcription of other angiogenesis-relevant genes}

Tetrac and Nanotetrac were shown to significantly increase the transcription of thrombospondin 1 , an endogenous inhibitor of angiogenesis commonly suppressed in cancer cells, including human medullary thyroid, breast, pancreas and oral cancer cells (Glinskii et al. 2009, Yalcin et al. 2010b, Yalcin et al. 2013, Lin et al. 2018). Microarray analysis of VEGF-stimulated human dermal microvascular endothelial cells has suggested that tetrac dose-dependently decreases the abundance of angiopoietin-2, but not angiopoietin-1. The latter contributes to the maturation of blood vessels and maintenance of the resting endothelial state, while its antagonist angiopoietin-2 enhances vascular permeability and destabilises the quiescent endothelium in preparation of vascular network expansion (Mousa et al. 2008, Somanath et al. 2009). Furthermore, the expression of mRNA for angiopoietin-like 1, 2 and 3, proposed pro-angiogenic factors, was subject to inhibition by tetrac, as were the mRNAs of three different matrix metalloproteinases (15, 19 and 24) (Hato et al. 2008, Mousa et al. 2008). The abundance of tissue inhibitor of metalloproteinase 3 , as the name suggests, a potent matrix metalloproteinase inhibitor, in contrast, was increased (Mousa et al. 2008). Similarly, in human multiple myeloma cell lines, tetrac inhibited matrix metalloproteinase 9 mRNA expression. Conditioned medium from these cells or from primary cells obtained from bone marrow aspirates from multiple myeloma patients treated with either tetrac or Nanotetrac had significantly decreased levels of matrix metalloproteinase 9 activity as shown by gelatin zymography (Cohen et al. 2014). Moreover, in the CAM assay, Nanotetrac inhibited the activity of lipopolysaccharide (LPS) and endogenous pro-angiogenic factors bradykinin and angiotensin II (Mousa et al. 2014). The underlying mechanisms are not known, though for bradykinin disruption of crosstalk between the integrin and VEGFR and/or FGFR by Nanotetrac has been proposed as the underlying mechanism (Davis et al. 2015).

On a slightly different note, Nanotetrac was shown to influence the cellular abundance of certain microRNAs (miRs), small non-coding RNAs that regulate gene transcription: anti-angiogenic microRNA miR-15A is increased and proangiogenic miR-21 decreased in human breast cancer cells upon treatment with Nanotetrac (Davis et al. 2014a).

\section{Effects of tetrac on tumour angiogenesis in vivo}

Both tetrac and its nanoparticulate formulation significantly reduced tumour angiogenesis as assessed by haemoglobin content both in the CAM assay and mouse xenografts implanted with human renal cell carcinoma, follicular thyroid carcinoma, medullary thyroid carcinoma, non-small cell lung cancer, pancreatic cancer and glioblastoma cells (Yalcin et al. 2009, 
2010a,b, 2013, Mousa et al. 2012, Davis et al. 2015). In a subcutaneous murine Lewis lung carcinoma model, tetrac significantly reduced haemoglobin content and VEGF protein levels in tumour tissue compared to untreated controls, and restored normal VEGF levels in tumours of T4-treated animals (Carmona-Cortés et al. 2014). Nanotetrac, when injected intratumourally at the time of implant or after 10 days of daily subcutaneous injections, was further shown to decrease the vascularity of subcutaneous human glioblastoma xenografts in mice by $95 \%$ as determined by histopathological analysis, without inducing haemorrhage (Sudha et al. 2017a). This study quite impressively demonstrates that tetrac not only inhibits neo-angiogenesis but also seems to cause de-vascularisation. In addition, Nanotetrac was shown to suppress the activity of NF-kB (nuclear factor kappa B) in human urinary bladder cancer xenografts in mice (Sudha et al. 2017b). This rapid response transcription factor is involved in stress response, is linked to cancer progression and is known to activate the transcription of pro-angiogenic mediators such as VEGF and IL-8, both directly and indirectly via activation of the hypoxia response pathway (Xie et al. 2010, Del Prete et al. 2011).

Hence, tetrac - independent of agonist thyroid hormone - affects the transcription and activity of various vascular growth factors, cytokines and other angiogenesis mediators, including miRs, as well as their respective receptors, cumulatively leading to reduced angiogenesis, an effect that is reflected by reduced angiogenesis in rodent tumour models.

\section{Effects on tumour stroma-associated mesenchymal stem cells}

The main body of evidence for integrin-mediated thyroid hormone effects in the context of cancer pertains to tumour cells and tumour-associated endothelial cells. However, mesenchymal stem cells, important progenitors to cell subtypes that comprise the tumour's fibrovascular network, are also integrin $\alpha v \beta 3$-positive and are subject to modulation by thyroid hormone and tetrac (Table 2) (Schmohl et al. 2015; Schmohl KA, Mueller AM, Dohmann M, Spellerberg R, Urnauer S, Schwenk N, Ziegler SI, Nelson PJ \& Spitzweg C, unpublished observations).

\section{Mesenchymal stem cells and angiogenesis}

Mesenchymal stem cells are multipotent nonhaematopoietic progenitor cells that selectively home to sites of tissue injury and contribute to tissue remodelling through differentiation and secretion of pro-angiogenic factors (Dwyer \& Kerin 2010). They play multifaceted roles in promoting angiogenesis and are involved in all stages, including the early steps of endothelial cell recruitment, but also in the maturation of newly formed vessels (Cuiffo \& Karnoub 2012, Bronckaers et al. 2014). In addition to the differentiation of mesenchymal stem cells into blood vessel-stabilising pericytes, their secretome contains a host of angiogenic factors that have been shown to alter endothelial cell behaviour.

Based on similarities between the wound-healing process and tumour stroma formation, mesenchymal stem cells are actively recruited to growing tumour stroma (Dvorak 1986, Knoop et al. 2011, 2015, Müller et al. 2016, Schug et al. 2019). Upon homing, they differentiate into cancer-associated fibroblast/pericyte-like cells that are characterised by the expression of pro-angiogenic factors and tumour-promoting growth factors (Mishra et al. 2008, Spaeth et al. 2009, Kidd et al. 2012, Barcellos-de-Souza et al. 2013, Schmohl et al. 2015; Schmohl KA, Mueller AM, Dohmann M, Spellerberg R, Urnauer S, Schwenk N, Ziegler SI, Nelson PJ \& Spitzweg C, unpublished observations).

\section{Thyroid hormone effects on mesenchymal stem cells}

Data from our own laboratory has demonstrated that primary human bone marrow-derived mesenchymal stem cells treated with thyroid hormone in the presence of tumour cell-conditioned medium (human hepatocellular carcinoma) show enhanced expression of genes associated with a cancer-associated fibroblast-like phenotype (Fig. 1). These include the pro-angiogenic vascular growth factors VEGF, FGF2 and placental growth factor, in addition to HIF- $1 \alpha$ and pro-angiogenic angiogenin and angiopoietin 2 . Furthermore, the expression of pericyte markers $\alpha$-smooth muscle actin and desmin is stimulated, as well as the expression of less specific growth factors and cytokines that have been associated with angiogenesis, for example EGF, hepatocyte growth factor, insulin-like growth factor 1, TGF- $\beta 1$ and IL- 6 . These effects are all inhibited by tetrac (Schmohl et al. 2015; Schmohl KA, Mueller AM, Dohmann M, Spellerberg R, Urnauer S, Schwenk N, Ziegler SI, Nelson PJ \& Spitzweg C, unpublished observations). Supernatant from thyroid hormone-stimulated mesenchymal stem cells enhances endothelial tube formation, while additional treatment with tetrac reduces tube formation to basal levels (Fig. 1) (Schmohl KA, Mueller AM, Dohmann M, Spellerberg R, Urnauer S, Schwenk N, Ziegler SI, Nelson PJ \& Spitzweg C, unpublished observations). We further observed that both VEGF signalling and the hypoxia 


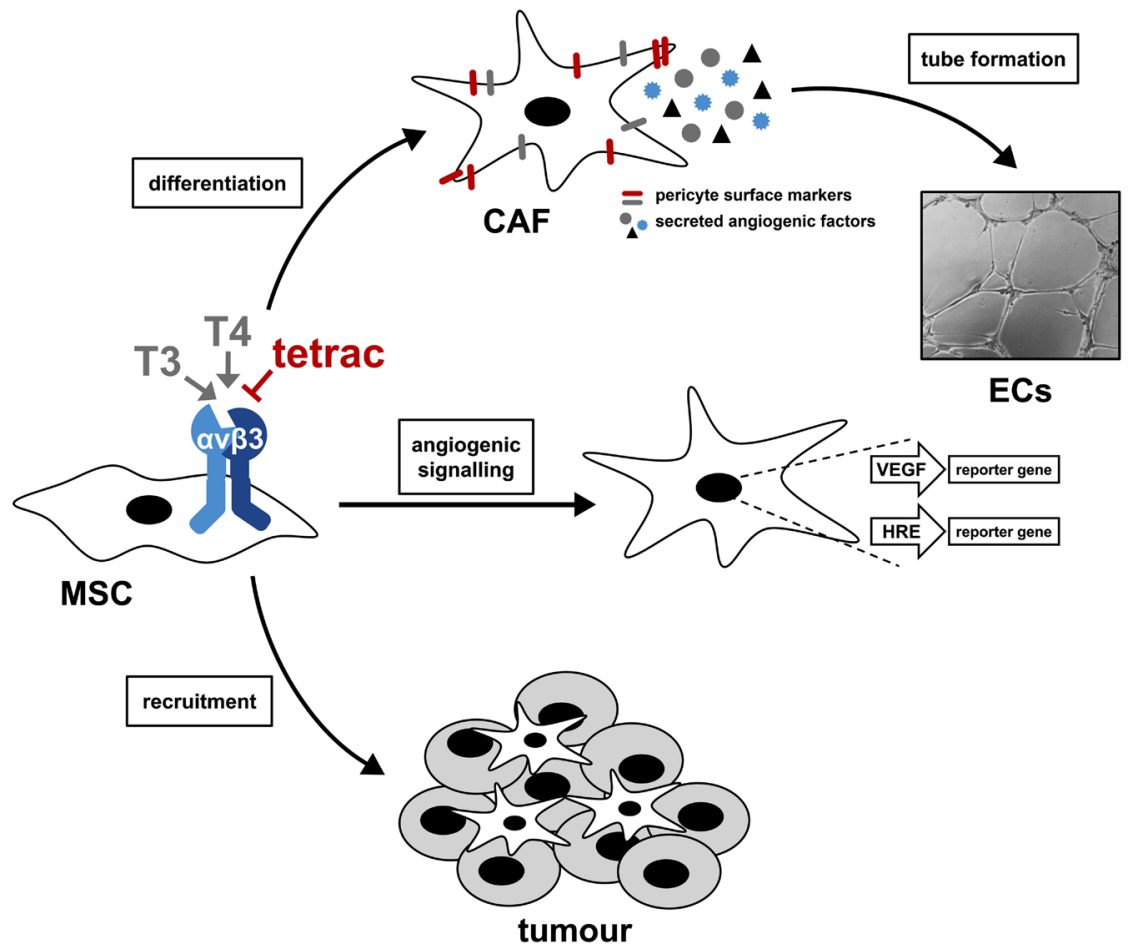

\section{Figure 1}

Tetrac blocks the pro-angiogenic effects of thyroid hormones on mesenchymal stem cells. Mesenchymal stem cells, important progenitor cells of a tumour's fibrovascular network, play diverse roles during angiogenesis. As they express integrin $\alpha \vee \beta 3$, they are susceptible to thyroid hormone and tetrac stimulation. Thyroid hormones increase the differentiation of mesenchymal stem cells towards a cancerassociated fibroblast/pericyte-like phenotype in the tumour environment, which leads to secretion of pro-angiogenic modulators that in turn stimulate endothelial cell tube formation. They further stimulate pro-angiogenic signalling through activation of the VEGF promoter and a hypoxia-inducible promoter. In addition, recruitment of mesenchymal stem cells to tumours is enhanced under thyroid hormone stimulation. All these effects are blocked by additional treatment with tetrac. MSC: mesenchymal stem cell; CAF: cancer-associated fibroblast; ECs: endothelial cells; VEGF: vascular endothelial growth factor; HRE: hypoxiaresponsive elements. response in mesenchymal stem cells are subject to thyroid hormone activation via integrin $\alpha v \beta 3$ in vitro (Fig. 1). By applying MSCs with a VEGF promoter-driven reporter gene construct in an orthotopic hepatocellular carcinoma mouse model, we observed enhanced VEGF signalling in tumour-recruited MSCs in hyperthyroid mice as compared to euthyroid mice, while in hypothyroid or tetrac-treated animals, reporter gene expression was markedly reduced (Schmohl KA, Mueller AM, Dohmann M, Spellerberg R, Urnauer S, Schwenk N, Ziegler SI, Nelson PJ \& Spitzweg C, unpublished observations).

In addition, thyroid hormone stimulates in vitro migration of mesenchymal stem cells towards tumour cell-conditioned medium and invasion into threedimensional tumour cell spheroids, an effect that is again blocked by tetrac. Recruitment in vivo was analysed in a subcutaneous xenograft mouse model of human hepatocellular carcinoma. Mesenchymal stem cells showed significantly higher recruitment to the perivascular regions of tumours with strong infiltration into the surrounding tumour tissue in hyperthyroid mice as compared to euthyroid mice, while recruitment was significantly reduced in hypothyroid mice. In euthyroid mice treated with tetrac, recruitment was nearly completely abolished (Schmohl et al. 2015). The significance of this observation is that tetrac not only counteracts the differentiation of mesenchymal stem cells towards a more pro-angiogenic phenotype under thyroid hormone stimulation, but also hampers their recruitment to their site of action in the tumour stroma (Fig. 1). Thus, mesenchymal stem cells as important tumour-supportive stroma cells have emerged as thyroid hormone-dependent targets via integrin $\alpha v \beta 3$.

\section{Discussion}

Only in recent years has it become clear that thyroid hormones act as small molecule pro-angiogenic modulators via integrin $\alpha v \beta 3$, and can support cancerrelated angiogenesis as well as drive tumour growth (reviewed in Goemann et al. 2017). These effects are obviously undesirable in cancer patients, and endogenous as well as exogenously applied thyroid hormone may limit the effectiveness of anticancer therapy (Mousa et al. 2014, Lin et al. 2015). Indeed, clinical data and populationbased studies have in part supported this notion.

Against this background, Hercbergs et al. have proposed to reconsider T4 supplementation as standard hormone replacement therapy for hypothyroidism, and have raised the issue whether and how cancer patients in need of supplementation should be treated (Hercbergs et al. 2016). Of note, in differentiated thyroid cancer patients, endogenous pituitary secretion of TSH, which stimulates differentiated thyroid cancer cell proliferation, is routinely suppressed by $\mathrm{T} 4 \mathrm{administration.} \mathrm{In} \mathrm{patients} \mathrm{with} \mathrm{recurrence} \mathrm{in} \mathrm{spite}$ 
of full TSH suppression, the tumour may switch from TSH-dependency to dependency on exogenously administered T4 (Hercbergs et al. 2016). As detailed above, the affinity for $\mathrm{T} 4$ is far higher than for $\mathrm{T} 3$ at the integrin, which is consistent with an often reported higher responsiveness to $\mathrm{T} 4$ than to $\mathrm{T} 3$ in experimental studies, suggesting that $\mathrm{T} 3$ supplementation may have an advantage over T4 supplementation, at least in a subset of patients (Davis et al. 2013b, 2018, Hercbergs et al. 2015, 2016). Clearly, before these novel findings will be able to enter the clinical arena, more clinical data in larger patient cohorts are needed to elucidate the diverse effects of thyroid hormones and its derivatives on different aspects of cancer biology, such as proliferation, angiogenesis, inflammation, migration, as well as immunological aspects - especially considering the high variability seen in clinical studies that have been undertaken to date.

Increasing evidence suggests that most cancerrelevant thyroid hormone effects are mediated by integrin $\alpha v \beta 3$. Therefore, blocking the integrin without affecting physiologic thyroid hormone signalling at nuclear TRs may be the more elegant, and less side effect-afflicted alternative - especially as the integrin is rarely expressed in high levels on normal cells. The advantage of tetrac over other integrin antagonists, specifically monoclonal antibodies or RGD-containing ligands, is that it does not inactivate the integrin, but allows selective manipulation of integrin function towards anticancer signalling (Davis et al. 2014b). Though focussed on a single specific receptor site, the anti-tumour actions of tetrac encompass multiple mechanisms downstream of the integrin. Besides interfering with numerous angiogenesis pathways, tetrac inhibits cancer cell proliferation, enhances cancer cell apoptosis and radio- and chemosensitises cancer cells (Rebbaa et al. 2008, Hercbergs et al. 2009, 2011, Lin et al. 2011, Davis et al. 2018). Furthermore, tetrac not only targets tumour endothelium and cancer cells themselves, but also affects mesenchymal stem cells as part of the tumour stroma. The tumour stroma plays a key role in tumour growth, angiogenesis and metastatic potential and has therefore emerged as a crucial target for cancer therapy. Tetrac blocks thyroid hormoneinduced stimulation of differentiation of mesenchymal stem cells towards a tumour-promoting cancer-associated fibroblast-like phenotype, blocks angiogenic signalling and also significantly reduces recruitment and invasion of these cells into the tumour (Schmohl et al. 2015; Schmohl KA, Mueller AM, Dohmann M, Spellerberg R, Urnauer S, Schwenk N, Ziegler SI, Nelson PJ \& Spitzweg C, unpublished observations).

\section{Conclusions}

In conclusion, over the last two decades, tremendous advances have been made in understanding the antiangiogenic and general anticancer properties of tetrac. Tetrac possesses multiple favourable characteristics for clinical application, including high cell/tissue selectivity, low toxicity and low cost. Despite the cornucopia of promising preclinical data and a number of patents filed, (Nano)tetrac has not yet undergone clinical trials. Clinical evaluation of tetrac is an exciting prospect that will hopefully become a reality over the next decade.

\section{Declaration of interest}

The authors declare that there is no conflict of interest that could be perceived as prejudicing the impartiality of this review.

\section{Funding}

Cited work from our laboratory was supported by grants from the Deutsche Forschungsgemeinschaft within the Priority Programme SPP1629 to C.S. (SP 581/6-1, SP 581/6-2) and P.J.N. (NE 648/5-2) and the Collaborative Research Centre SFB 824 (project C8) to C.S. as well as a grant from the Wilhelm-Sander-Stiftung (2014.129.1) to C.S.

\section{References}

Angelousi A, Diamanti-Kandarakis E, Zapanti E, Nonni A, Ktenas E, Mantzou A, Kontzoglou K \& Kouraklis G 2017 Is there an association between thyroid function abnormalities and breast cancer? Archives of Endocrinology and Metabolism 61 54-61. (https://doi. org/10.1590/2359-3997000000191)

Ashur-Fabian O, Blumenthal DT, Bakon M, Nass D, Davis PJ \& Hercbergs A 2013 Long-term response in high-grade optic glioma treated with medically induced hypothyroidism and carboplatin: a case report and review of the literature. Anti-Cancer Drugs 24 315-323. (https://doi.org/10.1097/CAD.0b013e32835c7a47)

Asvold BO, Bjøro T, Nilsen TI \& Vatten LJ 2007 Tobacco smoking and thyroid function: a population-based study. Archives of Internal Medicine 167 1428-1432. (https://doi.org/10.1001/ archinte.167.13.1428)

Avraamides CJ, Garmy-Susini B \& Varner JA 2008 Integrins in angiogenesis and lymphangiogenesis. Nature Reviews. Cancer $\mathbf{8}$ 604-617. (https://doi.org/10.1038/nrc2353)

Baldazzi V, Tassi R, Lapini A, Santomaggio C, Carini M \& Mazzanti R 2012 The impact of sunitinib-induced hypothyroidism on progression-free survival of metastatic renal cancer patients: a prospective single-center study. Urologic Oncology 30 704-710. (https://doi.org/10.1016/j.urolonc.2010.07.015)

Balzan S, Del Carratore R, Nardulli C, Sabatino L, Lubrano V \& Iervasi G 2013 The stimulative effect of T3 and T4 on human myocardial endothelial cell proliferation, migration and angiogenesis. Journal of Clinical and Experimental Cardiology 4 280-286. (https://doi. org/10.4172/2155-9880.1000280)

Barcellos-de-Souza P, Gori V, Bambi F \& Chiarugi P 2013 Tumor microenvironment: bone marrow-mesenchymal stem cells as key players. Biochimica et Biophysica Acta 1836 321-335. (https://doi. org/10.1016/j.bbcan.2013.10.004) 
Beatson GT 1896 On the treatment of inoperable cases of carcinoma of the mamma: suggestions for a new method of treatment, with illustrative cases. Transactions. Medico-Chirurgical Society of Edinburgh 15 153-179.

Belin RM, Astor BC, Powe NR \& Ladenson PW 2004 Smoke exposure is associated with a lower prevalence of serum thyroid autoantibodies and thyrotropin concentration elevation and a higher prevalence of mild thyrotropin concentration suppression in the third National Health and Nutrition Examination Survey (NHANES III). Journal of Clinical Endocrinology and Metabolism 89 6077-6086. (https://doi. org/10.1210/jc.2004-0431)

Bergh JJ, Lin HY, Lansing L, Mohamed SN, Davis FB, Mousa S \& Davis PJ 2005 Integrin alphaVbeta3 contains a cell surface receptor site for thyroid hormone that is linked to activation of mitogen-activated protein kinase and induction of angiogenesis. Endocrinology 146 2864-2871. (https://doi.org/10.1210/en.2005-0102)

Bharali DJ, Yalcin M, Davis PJ \& Mousa SA 2013 Tetraiodothyroacetic acid-conjugated PLGA nanoparticles: a nanomedicine approach to treat drug-resistant breast cancer. Nanomedicine 8 1943-1954. (https://doi.org/10.2217/nnm.12.200)

Brandt J, Borgquist S, Almquist M \& Manjer J 2016 Thyroid function and survival following breast cancer. British Journal of Surgery 103 1649-1657. (https://doi.org/10.1002/bjs.10284)

Brent GA 2012 Mechanisms of thyroid hormone action. Journal of Clinical Investigation 122 3035-3043. (https://doi.org/10.1172/JCI60047)

Bronckaers A, Hilkens P, Martens W, Gervois P, Ratajczak J, Struys T \& Lambrichts I 2014 Mesenchymal stem/stromal cells as a pharmacological and therapeutic approach to accelerate angiogenesis. Pharmacology and Therapeutics 143 181-196. (https:// doi.org/10.1016/j.pharmthera.2014.02.013)

Brooks PC, Clark RA \& Cheresh DA 1994 Requirement of vascular integrin alpha v beta 3 for angiogenesis. Science 264 569-571. (https://doi.org/10.1126/science.7512751)

Buda-Nowak A, Kucharz J, Dumnicka P, Kuzniewski M, Herman RM, Zygulska AL \& Kusnierz-Cabala B 2017 Sunitinib-induced hypothyroidism predicts progression-free survival in metastatic renal cell carcinoma patients. Medical Oncology 34 68. (https://doi. org/10.1007/s12032-017-0928z)

Burger AG, Engler D, Sakoloff C \& Staeheli V 1979 The effects of tetraiodothyroacetic and triiodothyroacetic acids on thyroid function in euthyroid and hyperthyroid subjects. Acta Endocrinologica 92 455-467. (https://doi.org/10.1530/acta.0.0920455)

Carmona-Cortés J, Rodriguez-Gómez I, Wangensteen R, Banegas I, García-Lora ÁM, Quesada A, Osuna A \& Vargas F 2014 Effect of thyroid hormone-nitric oxide interaction on tumor growth, angiogenesis, and aminopeptidase activity in mice. Tumour Biology 35 5519-5526. (https://doi.org/10.1007/s13277-014-1726-2)

Chan YX, Knuiman MW, Divitini ML, Brown SJ, Walsh J \& Yeap BB 2017 Lower TSH and higher free thyroxine predict incidence of prostate but not breast, colorectal or lung cancer. European Journal of Endocrinology 177 297-308. (https://doi.org/10.1530/EJE-17-0197)

Cheng SY, Leonard JL \& Davis PJ 2010 Molecular aspects of thyroid hormone actions. Endocrine Reviews 31 139-170. (https://doi. org/10.1210/er.2009-0007)

Chilian WM, Wangler RD, Peters KG, Tomanek RJ \& Marcus ML 1985 Thyroxine-induced left ventricular hypertrophy in the rat. Anatomical and physiological evidence for angiogenesis. Circulation Research 57 591-598. (https://doi.org/10.1161/01.RES.57.4.591)

Cody V, Davis PJ \& Davis FB 2007 Molecular modeling of the thyroid hormone interactions with alpha $\mathrm{v}$ beta 3 integrin. Steroids $\mathbf{7 2}$ 165-170. (https://doi.org/10.1016/j.steroids.2006.11.008)

Cohen K, Flint N, Shalev S, Erez D, Baharal T, Davis PJ, Hercbergs A, Ellis M \& Ashur-Fabian O 2014 Thyroid hormone regulates adhesion, migration and matrix metalloproteinase 9 activity via $\alpha v \beta 3$ integrin in myeloma cells. Oncotarget 5 6312-6322. (https://doi. org/10.18632/oncotarget.2205)
Cristofanilli M, Yamamura Y, Kau SW, Bevers T, Strom S, Patangan M, Hsu L, Krishnamurthy S, Theriault RL \& Hortobagyi GN 2005 Thyroid hormone and breast carcinoma. Primary hypothyroidism is associated with a reduced incidence of primary breast carcinoma. Cancer 103 1122-1128. (https://doi.org/10.1002/cncr.20881)

Cuiffo BG \& Karnoub AE 2012 Mesenchymal stem cells in tumor development: emerging roles and concepts. Cell Adhesion and Migration 6 220-230. (https://doi.org/10.4161/cam.20875)

Davis FB, Mousa SA, O'Connor L, Mohamed S, Lin HY, Cao HJ \& Davis PJ 2004 Proangiogenic action of thyroid hormone is fibroblast growth factor-dependent and is initiated at the cell surface. Circulation Research 94 1500-1506. (https://doi.org/10.1161/01. RES.0000130784.90237.4a)

Davis PJ, Glinsky GV, Lin HY, Incerpi S, Davis FB, Mousa SA, Tang HY, Hercbergs A \& Luidens MK 2013a Molecular mechanisms of actions of formulations of the thyroid hormone analogue, tetrac, on the inflammatory response. Endocrine Research 38 112-118. (https://doi. org/10.3109/07435800.2013.778865)

Davis PJ, Lin HY, Tang HY, Davis FB \& Mousa SA 2013b Adjunctive input to the nuclear thyroid hormone receptor from the cell surface receptor for the hormone. Thyroid 23 1503-1509. (https://doi. org/10.1089/thy.2013.0280)

Davis PJ, Mousa SA, Cody V, Tang HY \& Lin HY 2013c Small molecule hormone or hormone-like ligands of integrin $\alpha \mathrm{V} \beta 3$ : implications for cancer cell behavior. Hormones and Cancer 4 335-342. (https://doi. org/10.1007/s12672-013-0156-8)

Davis PJ, Glinsky GV, Lin HY, Leith JT, Hercbergs A, Tang HY, AshurFabian O, Incerpi S \& Mousa SA 2014a Cancer cell gene expression modulated from plasma membrane integrin $\alpha v \beta 3$ by thyroid hormone and nanoparticulate tetrac. Frontiers in Endocrinology 5240. (https://doi.org/10.3389/fendo.2014.00240)

Davis PJ, Lin HY, Sudha T, Yalcin M, Tang HY, Hercbergs A, Leith JT, Luidens MK, Ashur-Fabian O, Incerpi S, et al. 2014b Nanotetrac targets integrin $\alpha v \beta 3$ on tumor cells to disorder cell defense pathways and block angiogenesis. OncoTargets and Therapy 7 1619-1624. (https://doi.org/10.2147/OTT.S67393)

Davis PJ, Sudha T, Lin HY \& Mousa SA 2015 Thyroid hormone, hormone analogs, and angiogenesis. Comprehensive Physiology 6 353-362. (https://doi.org/10.1002/cphy.c150011)

Davis PJ, Glinsky GV, Lin HY \& Mousa SA 2016 Actions of thyroid hormone analogues on chemokines. Journal of Immunology Research 2016 3147671. (https://doi.org/10.1155/2016/3147671)

Davis PJ, Leonard JL, Lin HY, Leinung M \& Mousa SA 2018 Molecular basis of nongenomic actions of thyroid hormone. Vitamins and Hormones 106 67-96. (https://doi.org/10.1016/bs.vh.2017.06.001)

Del Prete A, Allavena P, Santoro G, Fumarulo R, Corsi MM \& Mantovani A 2011 Molecular pathways in cancer-related inflammation. Biochemia Medica 21 264-275. (https://doi. org/10.11613/BM.2011.036)

Deryugina EI \& Quigley JP 2015 Tumor angiogenesis: MMP-mediated induction of intravasation- and metastasis-sustaining neovasculature. Matrix Biology 44-46 94-112. (https://doi.org/10.1016/j. matbio.2015.04.004)

Desgrosellier JS \& Cheresh DA 2010 Integrins in cancer: biological implications and therapeutic opportunities. Nature Reviews. Cancer 10 9-22. (https://doi.org/10.1038/nrc2748)

Dijkgraaf I, Beer AJ \& Wester HJ 2009 Application of RGD-containing peptides as imaging probes for alphavbeta3 expression. Frontiers in Bioscience 14 887-899. (https://doi.org/10.2741/3284)

Dvorak HF 1986 Tumors: wounds that do not heal. Similarities between tumor stroma generation and wound healing. New England Journal of Medicine 315 1650-1659. (https://doi.org/10.1056/ NEJM198612253152606)

Dwyer RM \& Kerin MJ 2010 Mesenchymal stem cells and cancer: tumorspecific delivery vehicles or therapeutic targets? Human Gene Therapy 21 1506-1512. (https://doi.org/10.1089/hum.2010.135) https://erc bioscientifica.com

https://doi.org/10.1530/ERC-19-0058 (c) 2019 Society for Endocrinology Published by Bioscientifica Ltd. Printed in Great Britain 
Ellis LM 2004 Epidermal growth factor receptor in tumor angiogenesis. Hematology/Oncology Clinics of North America 18 1007-1021. (https:// doi.org/10.1016/j.hoc.2004.06.002)

Freedberg AS, Hamolsky MW \& Stein M 1957 The thyroid hormoneplasma protein complex in man. II. A new in vitro method for study of uptake of labelled hormonal components by human erythrocytes. Journal of Clinical Endocrinology and Metabolism 17 33-43. (https:// doi.org/10.1210/jcem-17-1-33)

Fujita M, Takada YK \& Takada Y 2014 The chemokine fractalkine can activate integrins without CX3CR1 through direct binding to a ligand-binding site distinct from the classical RGD-binding site. PLoS ONE 9 e96372. (https://doi.org/10.1371/journal.pone.0096372)

Gao R, Liang JH, Wang L, Zhu HY, Wu W, Wu JZ, Xia Y, Cao L, Fan L, Yang T, et al. 2017 Low T3 syndrome is a strong prognostic predictor in diffuse large B cell lymphoma. British Journal of Haematology $\mathbf{1 7 7}$ 95-105. (https://doi.org/10.1111/bjh.14528)

Glinskii AB, Glinsky GV, Lin HY, Tang HY, Sun M, Davis FB, Luidens MK, Mousa SA, Hercbergs AH \& Davis PJ 2009 Modification of survival pathway gene expression in human breast cancer cells by tetraiodothyroacetic acid (tetrac). Cell Cycle 8 3562-3570. (https:// doi.org/10.4161/cc.8.21.9963)

Goda S, Imai T, Yoshie O, Yoneda O, Inoue H, Nagano Y, Okazaki T, Imai H, Bloom ET, Domae N, et al. 2000 CX3C-chemokine, fractalkine-enhanced adhesion of THP-1 cells to endothelial cells through integrin-dependent and -independent mechanisms. Journal of Immunology 164 4313-4320. (https://doi.org/10.4049/ jimmunol.164.8.4313)

Goemann IM, Romitti M, Meyer ELS, Wajner SM \& Maia AL 2017 Role of thyroid hormones in the neoplastic process: an overview. Endocrine-Related Cancer 24 R367-R385. (https://doi.org/10.1530/ ERC-17-0192)

Ha CH, Wang W, Jhun BS, Wong C, Hausser A, Pfizenmaier K, McKinsey TA, Olson EN \& Jin ZG 2008 Protein kinase D-dependent phosphorylation and nuclear export of histone deacetylase 5 mediates vascular endothelial growth factor-induced gene expression and angiogenesis. Journal of Biological Chemistry 283 14590-14599. (https://doi.org/10.1074/jbc.M800264200)

Hamolsky MW, Golodetz A \& Freedberg AS 1959 The plasma proteinthyroid hormone complex in man. III. Further studies on the use of the in vitro red blood cell up take of I 131-1-triiodothyronine as a diagnostic test of thyroid function. Journal of Clinical Endocrinology and Metabolism 19 103-116. (https://doi.org/10.1210/jcem-19-1-103)

Hato T, Tabata M \& Oike Y 2008 The role of angiopoietin-like proteins in angiogenesis and metabolism. Trends in Cardiovascular Medicine $\mathbf{1 8}$ 6-14. (https://doi.org/10.1016/j.tcm.2007.10.003)

Hellevik AI, Asvold BO, Bjøro T, Romundstad PR, Nilsen TI \& Vatten LJ 2009 Thyroid function and cancer risk: a prospective population study. Cancer Epidemiology, Biomarkers and Prevention 18 570-574. (https://doi.org/10.1158/1055-9965.EPI-08-0911)

Hercbergs A \& Leith JT 1993 Spontaneous remission of metastatic lung cancer following myxedema coma--an apoptosis-related phenomenon? Journal of the National Cancer Institute 85 1342-1343. (https://doi.org/10.1093/jnci/85.16.1342)

Hercbergs AA, Goyal LK, Suh JH, Lee S, Reddy CA, Cohen BH, Stevens GH, Reddy SK, Peereboom DM, Elson PJ, et al. 2003 Propylthiouracil-induced chemical hypothyroidism with high-dose tamoxifen prolongs survival in recurrent high grade glioma: a phase I/II study. Anticancer Research 23 617-626.

Hercbergs A, Davis PJ, Davis FB, Ciesielski MJ \& Leith JT 2009 Radiosensitization of GL261 glioma cells by tetraiodothyroacetic acid (tetrac). Cell Cycle 8 2586-2591. (https://doi.org/10.4161/ cc.8.16.9328)

Hercbergs AH, Ashur-Fabian O \& Garfield D 2010 Thyroid hormones and cancer: clinical studies of hypothyroidism in oncology. Current Opinion in Endocrinology, Diabetes, and Obesity 17 432-436. (https:// doi.org/10.1097/MED.0b013e32833d9710)
Hercbergs AH, Lin HY, Davis FB, Davis PJ \& Leith JT 2011 Radiosensitization and production of DNA double-strand breaks in U87MG brain tumor cells induced by tetraiodothyroacetic acid (tetrac). Cell Cycle 10 352-357. (https://doi.org/10.4161/cc.10.2.14641)

Hercbergs AH, Davis FB, Lin HY, Luidens MK, Meng R, Ashur-Fabian O, Mousa SA \& Davis PJ 2012 Integrin-mediated actions of thyroid hormone analogues on tumor cell chemosensitivity, integrin-growth factor receptor crosstalk and inflammatory gene expression. Cancer and Clinical Oncology 1 32-40. (https://doi.org/10.5539/cco.v1n1p32)

Hercbergs A, Johnson RE, Ashur-Fabian O, Garfield DH \& Davis PJ 2015 Medically induced euthyroid hypothyroxinemia may extend survival in compassionate need cancer patients: an observational study. Oncologist 20 72-76. (https://doi.org/10.1634/ theoncologist.2014-0308)

Hercbergs A, Davis PJ, Lin HY \& Mousa SA 2016 Possible contributions of thyroid hormone replacement to specific behaviors of cancer. Biomedicine and Pharmacotherapy 84 655-659. (https://doi. org/10.1016/j.biopha.2016.09.053)

Incerpi S, Hsieh MT, Lin HY, Cheng GY, De Vito P, Fiore AM, Ahmed RG, Salvia R, Candelotti E, Leone S, et al. 2014 Thyroid hormone inhibition in L6 myoblasts of IGF-I-mediated glucose uptake and proliferation: new roles for integrin $\alpha v \beta 3$. American Journal of Physiology. Cell Physiology 307 C150-C161. (https://doi. org/10.1152/ajpcell.00308.2013)

Jiskra J, Barkmanova J, Limanova Z, Lánská V, Smutek D, Potlukova E \& Antosova M 2007 Thyroid autoimmunity occurs more frequently in women with breast cancer compared to women with colorectal cancer and controls but it has no impact on relapse-free and overall survival. Oncology Reports 18 1603-1611. (https://doi.org/10.3892/or.18.6.1603)

Johnstone CN, Chand A, Putoczki TL \& Ernst M 2015 Emerging roles for IL-11 signaling in cancer development and progression: focus on breast cancer. Cytokine and Growth Factor Reviews 26 489-498. (https://doi.org/10.1016/j.cytogfr.2015.07.015)

Jorde R \& Sundsfjord J 2006 Serum TSH levels in smokers and nonsmokers. The 5th Tromsø study. Experimental and Clinical Endocrinology and Diabetes 114 343-347. (https://doi. org/10.1055/s-2006-924264)

Keeley EC, Mehrad B \& Strieter RM 2010 CXC chemokines in cancer angiogenesis and metastases. Advances in Cancer Research 106 91-111. (https://doi.org/10.1016/S0065-230X(10)06003-3)

Khan SR, Chaker L, Ruiter R, Aerts JG, Hofman A, Dehghan A, Franco OH, Stricker BH \& Peeters RP 2016 Thyroid function and cancer risk: the Rotterdam Study. Journal of Clinical Endocrinology and Metabolism 101 5030-5036. (https://doi.org/10.1210/jc.2016-2104)

Kidd S, Spaeth E, Watson K, Burks J, Lu H, Klopp A, Andreeff M \& Marini FC 2012 Origins of the tumor microenvironment: quantitative assessment of adipose-derived and bone marrow-derived stroma. PLOS ONE 7 e30563. (https://doi.org/10.1371/journal. pone.0030563)

Kirkiles-Smith NC, Mahboubi K, Plescia J, McNiff JM, Karras J, Schechner JS, Altieri DC \& Pober JS 2004 IL-11 protects human microvascular endothelium from alloinjury in vivo by induction of survivin expression. Journal of Immunology 172 1391-1396. (https:// doi.org/10.4049/jimmunol.172.3.1391)

Knoop K, Kolokythas M, Klutz K, Willhauck MJ, Wunderlich N, Draganovici D, Zach C, Gildehaus FJ, Böning G, Göke B, et al. 2011 Image-guided, tumor stroma-targeted 131I therapy of hepatocellular cancer after systemic mesenchymal stem cell-mediated NIS gene delivery. Molecular Therapy 19 1704-1713. (https://doi.org/10.1038/ mt.2011.93)

Knoop K, Schwenk N, Schmohl K, Müller A, Zach C, Cyran C, Carlsen J, Böning G, Bartenstein P, Göke B, et al. 2015 Mesenchymal stem cellmediated, tumor stroma-targeted radioiodine therapy of metastatic colon cancer using the sodium iodide symporter as theranostic gene. Journal of Nuclear Medicine 56 600-606. (https://doi.org/10.2967/ jnumed.114.146662) 
Kumar MS, Chiang T \& Deodhar SD 1979 Enhancing effect of thyroxine on tumor growth and metastases in syngeneic mouse tumor systems. Cancer Research 39 3515-3518.

Kust D, Prpić M, Murgić J, Jazvić M, Jakšić B, Krilić D, Bolanča A \& Kusić Z 2014 Hypothyroidism as a predictive clinical marker of better treatment response to sunitinib therapy. Anticancer Research 34 3177-3184.

Lechner MG, Vyas CM, Hamnvik OR, Alexander EK, Larsen PR, Choueiri TK \& Angell TE 2018a Hypothyroidism during tyrosine kinase inhibitor therapy is associated with longer survival in patients with advanced nonthyroidal cancers. Thyroid 28 445-453. (https:// doi.org/10.1089/thy.2017.0587)

Lechner MG, Vyas CM, Hamnvik OR, Alexander EK, Larsen PR, Choueiri TK \& Angell TE $2018 b$ Risk factors for new hypothyroidism during tyrosine kinase inhibitor therapy in advanced nonthyroidal cancer patients. Thyroid 28 437-444. (https://doi.org/10.1089/ thy.2017.0579)

Lehrer S, Diamond EJ, Bajwa AM, Kornreich R, Stagger S, Stone NN, Droller MJ \& Stock RG 2001 Association between serum triiodothyronine (t3) level and risk of disease recurrence in men with localized prostate cancer. Prostate Cancer and Prostatic Diseases 4 232-234. (https://doi.org/10.1038/sj.pcan.4500542)

Li Y, Huang J, Hongtao T, Hongyan H, Hongzhong L \& Ren G 2016 Prognostic significance of CCL20 and its receptor CCR6 in cancers: a meta-analysis. International Journal of Clinical and Experimental Medicine 9 1908-1919.

Lin HY, Davis FB, Gordinier JK, Martino LJ \& Davis PJ 1999a Thyroid hormone induces activation of mitogen-activated protein kinase in cultured cells. American Journal of Physiology 276 C1014-C1024. (https://doi.org/10.1152/ajpcell.1999.276.5.C1014)

Lin HY, Shih A, Davis FB \& Davis PJ 1999b Thyroid hormone promotes the phosphorylation of STAT3 and potentiates the action of epidermal growth factor in cultured cells. Biochemical Journal 338 427-432. (https://doi.org/10.1042/bj3380427)

Lin HY, Sun M, Tang HY, Lin C, Luidens MK, Mousa SA, Incerpi S, Drusano GL, Davis FB \& Davis PJ 2009 L-thyroxine vs. 3,5,3'-triiodoL-thyronine and cell proliferation: activation of mitogen-activated protein kinase and phosphatidylinositol 3-kinase. American Journal of Physiology. Cell Physiology 296 C980-C991. (https://doi.org/10.1152/ ajpcell.00305.2008)

Lin HY, Cody V, Davis FB, Hercbergs AA, Luidens MK, Mousa SA \& Davis PJ 2011 Identification and functions of the plasma membrane receptor for thyroid hormone analogues. Discovery Medicine $\mathbf{1 1}$ 337-347.

Lin HY, Tang HY, Davis FB, Mousa SA, Incerpi S, Luidens MK, Meng R \& Davis PJ 2012 Nongenomic regulation by thyroid hormone of plasma membrane ion and small molecule pumps. Discovery Medicine 14 199-206.

Lin HY, Su YF, Hsieh MT, Lin S, Meng R, London D, Lin C, Tang HY, Hwang J, Davis FB, et al. 2013 Nuclear monomeric integrin $\alpha \mathrm{v}$ in cancer cells is a coactivator regulated by thyroid hormone. FASEB Journal 27 3209-3216. (https://doi.org/10.1096/fj.12-227132)

Lin HY, Glinsky GV, Mousa SA \& Davis PJ 2015 Thyroid hormone and anti-apoptosis in tumor cells. Oncotarget 6 14735-14743. (https://doi. org/10.18632/oncotarget.4023)

Lin SJ, Chin YT, Ho Y, Chou SY, Sh Yang YC, Nana AW, Su KW, Lim YT, Wang K, Lee SY, et al. 2018 Nano-diamino-tetrac (NDAT) inhibits PD-L1 expression which is essential for proliferation in oral cancer cells. Food and Chemical Toxicology 120 1-11. (https://doi. org/10.1016/j.fct.2018.06.058)

Liu R, Li Z, Bai S, Zhang H, Tang M, Lei Y, Chen L, Liang S, Zhao YL, Wei Y, et al. 2009 Mechanism of cancer cell adaptation to metabolic stress: proteomics identification of a novel thyroid hormone-mediated gastric carcinogenic signaling pathway. Molecular and Cellular Proteomics 8 70-85. (https://doi.org/10.1074/ mcp.M800195-MCP200)
Liu X, Zheng N, Shi YN, Yuan J \& Li L 2014 Thyroid hormone induced angiogenesis through the integrin $\alpha v \beta 3$ /protein kinase $\mathrm{D} /$ histone deacetylase 5 signaling pathway. Journal of Molecular Endocrinology 52 245-254. (https://doi.org/10.1530/JME-13-0252)

Luidens MK, Mousa SA, Davis FB, Lin HY \& Davis PJ 2010 Thyroid hormone and angiogenesis. Vascular Pharmacology 52 142-145. (https://doi.org/10.1016/j.vph.2009.10.007)

Marone G \& Granata F 2014 Angiogenesis, lymphangiogenesis and clinical implications. Preface. Chemical Immunology and Allergy 99 XI-XII. (https://doi.org/10.1159/000352074)

Martinez-Iglesias O, Garcia-Silva S, Regadera J \& Aranda A 2009 Hypothyroidism enhances tumor invasiveness and metastasis development. PLoS ONE 4 e6428. (https://doi.org/10.1371/journal. pone.0006428)

Mehrad B, Keane MP \& Strieter RM 2007 Chemokines as mediators of angiogenesis. Thrombosis and Haemostasis 97 755-762. (https://doi. org/10.1160/TH07-01-0040)

Mehran L, Amouzgar A, Delshad H \& Azizi F 2012 The association of cigarette smoking with serum TSH concentration and thyroperoxidase antibody. Experimental and Clinical Endocrinology and Diabetes 120 80-83. (https://doi.org/10.1055/s-0031-1285910)

Meng W, Xue S \& Chen Y 2018 The role of CXCL12 in tumor microenvironment. Gene 641 105-110. (https://doi.org/10.1016/j. gene.2017.10.015)

Middleton K, Jones J, Lwin Z \& Coward JI 2014 Interleukin-6: an angiogenic target in solid tumours. Critical Reviews in Oncology/ Hematology 89 129-139. (https://doi.org/10.1016/j. critrevonc.2013.08.004)

Mishkin SY, Pollack R, Yalovsky MA, Morris HP \& Mishkin S 1981 Inhibition of local and metastatic hepatoma growth and prolongation of survival after induction of hypothyroidism. Cancer Research 41 3040-3045.

Mishra PJ, Mishra PJ, Humeniuk R, Medina DJ, Alexe G, Mesirov JP, Ganesan S, Glod JW \& Banerjee D 2008 Carcinoma-associated fibroblastlike differentiation of human mesenchymal stem cells. Cancer Research 68 4331-4339. (https://doi.org/10.1158/0008-5472.CAN-08-0943)

Moeller LC \& Führer D 2013 Thyroid hormone, thyroid hormone receptors, and cancer: a clinical perspective. Endocrine-Related Cancer 20 R19-R29. (https://doi.org/10.1530/ERC-12-0219)

Moeller LC, Dumitrescu AM \& Refetoff S 2005 Cytosolic action of thyroid hormone leads to induction of hypoxia-inducible factor1alpha and glycolytic genes. Molecular Endocrinology 19 2955-2963. (https://doi.org/10.1210/me.2004-0542)

Moeller LC, Cao X, Dumitrescu AM, Seo H \& Refetoff S 2006 Thyroid hormone mediated changes in gene expression can be initiated by cytosolic action of the thyroid hormone receptor beta through the phosphatidylinositol 3-kinase pathway. Nuclear Receptor Signaling 4 e020. (https://doi.org/10.1621/nrs.04020)

Moreno M, de Lange P, Lombardi A, Silvestri E, Lanni A \& Goglia F 2008 Metabolic effects of thyroid hormone derivatives. Thyroid $\mathbf{1 8}$ 239-253. (https://doi.org/10.1089/thy.2007.0248)

Mousa SA, Davis FB, Mohamed S, Davis PJ \& Feng X 2006 Proangiogenesis action of thyroid hormone and analogs in a threedimensional in vitro microvascular endothelial sprouting model. International Angiology 25 407-413.

Mousa SA, Bergh JJ, Dier E, Rebbaa A, O'Connor LJ, Yalcin M, Aljada A, Dyskin E, Davis FB, Lin HY, et al. 2008 Tetraiodothyroacetic acid, a small molecule integrin ligand, blocks angiogenesis induced by vascular endothelial growth factor and basic fibroblast growth factor. Angiogenesis 11 183-190. (https://doi.org/10.1007/s10456-007-90887)

Mousa SA, Yalcin M, Bharali DJ, Meng R, Tang HY, Lin HY, Davis FB \& Davis PJ 2012 Tetraiodothyroacetic acid and its nanoformulation inhibit thyroid hormone stimulation of non-small cell lung cancer cells in vitro and its growth in xenografts. Lung Cancer 76 39-45. (https://doi.org/10.1016/j.lungcan.2011.10.003) 
Mousa SA, Lin HY, Tang HY, Hercbergs A, Luidens MK \& Davis PJ 2014 Modulation of angiogenesis by thyroid hormone and hormone analogues: implications for cancer management. Angiogenesis $\mathbf{1 7}$ 463-469. (https://doi.org/10.1007/s10456-014-9418-5)

Müller AM, Schmohl KA, Knoop K, Schug C, Urnauer S, Hagenhoff A, Clevert DA, Ingrisch M, Niess H, Carlsen J, et al. 2016 Hypoxiatargeted 131I therapy of hepatocellular cancer after systemic mesenchymal stem cell-mediated sodium iodide symporter gene delivery. Oncotarget 7 54795-54810. (https://doi.org/10.18632/ oncotarget.10758)

Nelson M, Hercbergs A, Rybicki L \& Strome M 2006 Association between development of hypothyroidism and improved survival in patients with head and neck cancer. Archives of Otolaryngology-Head and Neck Surgery 132 1041-1046. (https://doi.org/10.1001/ archotol.132.10.1041)

Nieberler M, Reuning U, Reichart F, Notni J, Wester HJ, Schwaiger M, Weinmüller M, Räder A, Steiger K \& Kessler H 2017 Exploring the role of RGD-recognizing integrins in cancer. Cancers 9 116. (https:// doi.org/10.3390/cancers9090116)

Oba J, Esmaeli B, Ellerhorst JA, Lyons GR, Milton DR, Wang WL, Macedo MP, Lazar AJ, Grimm EA \& Chattopadhyay C 2017 Trends in hepatocyte growth factor, insulin-like growth factor 1, thyroidstimulating hormone, and leptin expression levels in uveal melanoma patient serum and tumor tissues: correlation to disease progression. Melanoma Research 27 126-133. (https://doi. org/10.1097/CMR.0000000000000329)

Ortega-Olvera C, Ulloa-Aguirre A, Angeles-Llerenas A, MaineroRatchelous FE, González-Acevedo CE, Hernández-Blanco ML, Ziv E, Avilés-Santa L, Pérez-Rodriguez E \& Torres-Mejia G 2018 Thyroid hormones and breast cancer association according to menopausal status and body mass index. Breast Cancer Research 20 94. (https:// doi.org/10.1186/s13058-018-1017-8)

Owen JL \& Mohamadzadeh M 2013 Macrophages and chemokines as mediators of angiogenesis. Frontiers in Physiology 4 159. (https://doi. org/10.3389/fphys.2013.00159)

Perra A, Plateroti M \& Columbano A 2016 T3/TRs axis in hepatocellular carcinoma: new concepts for an old pair. Endocrine-Related Cancer 23 R353-R369. (https://doi.org/10.1530/ERC-16-0152)

Pinto M, Soares P \& Ribatti D 2011 Thyroid hormone as a regulator of tumor induced angiogenesis. Cancer Letters 301 119-126. (https:// doi.org/10.1016/j.canlet.2010.11.011)

Raman D, Sobolik-Delmaire T \& Richmond A 2011 Chemokines in health and disease. Experimental Cell Research 317 575-589. (https:// doi.org/10.1016/j.yexcr.2011.01.005)

Rebbaa A, Chu F, Davis FB, Davis PJ \& Mousa SA 2008 Novel function of the thyroid hormone analog tetraiodothyroacetic acid: a cancer chemosensitizing and anti-cancer agent. Angiogenesis 11 269-276. (https://doi.org/10.1007/s10456-008-9110-8)

Reid I, Sharpe I, McDevitt J, Maxwell W, Emmons R, Tanner WA \& Monson JR 1991 Thyroid dysfunction can predict response to immunotherapy with interleukin-2 and interferon-2 alpha. British Journal of Cancer 64 915-918. (https://doi.org/10.1038/ bjc.1991.426)

Riesenbeck LM, Bierer S, Hoffmeister I, Köpke T, Papavassilis P, Hertle L, Thielen B \& Herrmann E 2011 Hypothyroidism correlates with a better prognosis in metastatic renal cancer patients treated with sorafenib or sunitinib. World Journal of Urology 29 807-813. (https:// doi.org/10.1007/s00345-010-0627-2)

Ruoslahti E \& Pierschbacher MD 1987 New perspectives in cell adhesion: RGD and integrins. Science 238 491-497. (https://doi. org/10.1126/science.2821619)

Ryu J, Lee CW, Hong KH, Shin JA, Lim SH, Park CS, Shim J, Nam KB, Choi KJ, Kim YH, et al. 2008 Activation of fractalkine/CX3CR1 by vascular endothelial cells induces angiogenesis through VEGF-A/KDR and reverses hindlimb ischaemia. Cardiovascular Research $\mathbf{7 8}$ 333-340. (https://doi.org/10.1093/cvr/cvm067)
Sabatier R, Eymard JC, Walz J, Deville JL, Narbonne H, Boher JM, Salem N, Marcy M, Brunelle S, Viens P, et al. 2012 Could thyroid dysfunction influence outcome in sunitinib-treated metastatic renal cell carcinoma? Annals of Oncology 23 714-721. (https://doi. org/10.1093/annonc/mdr275)

Saraiva PP, Figueiredo NB, Padovani CR, Brentani MM \& Nogueira CR 2005 Profile of thyroid hormones in breast cancer patients. Brazilian Journal of Medical and Biological Research 38 761-765. (https://doi. org//S0100-879X2005000500014)

Schmidinger M, Vogl UM, Bojic M, Lamm W, Heinzl H, Haitel A, Clodi M, Kramer G \& Zielinski CC 2011 Hypothyroidism in patients with renal cell carcinoma: blessing or curse? Cancer 117 534-544. (https://doi.org/10.1002/cncr.25422)

Schmohl KA, Müller AM, Wechselberger A, Rühland S, Salb N, Schwenk N, Heuer H, Carlsen J, Göke B, Nelson PJ, et al. 2015 Thyroid hormones and tetrac: new regulators of tumour stroma formation via integrin $\alpha v \beta 3$. Endocrine-Related Cancer 22 941-952. (https://doi.org/10.1530/ERC-15-0245)

Schug C, Gupta A, Urnauer S, Steiger K, Cheung PF, Neander C, Savvatakis K, Schmohl KA, Trajkovic-Arsic M, Schwenk N, et al. 2019 A novel approach for image-guided ${ }^{131}$ I therapy of pancreatic ductal adenocarcinoma using mesenchymal stem cell-mediated NIS gene delivery. Molecular Cancer Research 17 310-320. (https://doi. org/10.1158/1541-7786.MCR-18-0185)

Schwartz HL, Carter AC, Singh SP, Kydd DM \& Costanzo RR, Jr 1968 Relationship of red blood cell 131-I-L-triiodothyronine binding coefficient and cell maturation. 3. Binding to mature erythrocyte and reticulocyte cell membranes. Endocrinology 82 569-574. (https:// doi.org/10.1210/endo-82-3-569)

Semenza GL 2010 Defining the role of hypoxia-inducible factor 1 in cancer biology and therapeutics. Oncogene 29 625-634. (https://doi. org/10.1038/onc.2009.441)

Shih A, Zhang S, Cao HJ, Tang HY, Davis FB, Davis PJ \& Lin HY 2004 Disparate effects of thyroid hormone on actions of epidermal growth factor and transforming growth factor-alpha are mediated by 3',5'-cyclic adenosine 5'-monophosphate-dependent protein kinase II. Endocrinology 145 1708-1717. (https://doi.org/10.1210/en.20030742)

Shoemaker JP, Bradley RL \& Hoffman RV 1976 Increased survival and inhibition of mammary tumors in hypothyroid mice. Journal of Surgical Research 21 151-154. (https://doi.org/10.1016/00224804(76)90151-7)

Singh SP, Carter AC, Kydd DM \& Costanzo RR, Jr 1976 Interaction between thyroid hormones and erythrocyte membranes: competitive inhibition of binding 131 I-L-triiodothyronine and 131 I-L-thyroxine by their analogs. Endocrine Research Communications 3 119-131. (https://doi.org/10.3109/07435807609052927)

Sinha R \& Yen PM 2000 Cellular action of thyroid hormone. In Endotext. Eds LJ De Groot, P Beck-Peccoz, G Chrousos, K Dungan, A Grossman, JM Hershman, C Koch, R Mclachlan, M New, R Rebar, et al. South Dartmouth, MA, USA: MDText.com, Inc. (available at: https://www.ncbi.nlm.nih.gov/books/NBK285568/)

Somanath PR, Ciocea A \& Byzova TV 2009 Integrin and growth factor receptor alliance in angiogenesis. Cell Biochemistry and Biophysics $\mathbf{5 3}$ 53-64. (https://doi.org/10.1007/s12013-008-9040-5)

Spaeth EL, Dembinski JL, Sasser AK, Watson K, Klopp A, Hall B, Andreeff M \& Marini F 2009 Mesenchymal stem cell transition to tumor-associated fibroblasts contributes to fibrovascular network expansion and tumor progression. PLoS ONE 4 e4992. (https://doi. org/10.1371/journal.pone.0004992)

Sudha T, Bharali DJ, Sell S, Darwish NHE, Davis PJ \& Mousa SA 2017a Nanoparticulate tetrac inhibits growth and vascularity of glioblastoma xenografts. Hormones and Cancer 8 157-165. (https:// doi.org/10.1007/s12672-017-0293-6)

Sudha T, Bharali DJ, Yalcin M, Darwish NH, Coskun MD, Keating KA, Lin HY, Davis PJ \& Mousa SA $2017 b$ Targeted delivery of cisplatin to 
tumor xenografts via the nanoparticle component of nano-diaminotetrac. Nanomedicine 12 195-205. (https://doi.org/10.2217/ nnm-2016-0315)

Szukiewicz D, Kochanowski J, Pyzlak M, Szewczyk G, Stangret A \& Mittal TK 2013 Fractalkine (CX3CL1) and its receptor CX3CR1 may contribute to increased angiogenesis in diabetic placenta. Mediators of Inflammation 2013 437576. (https://doi.org/10.1155/2013/437576)

Theodossiou C \& Schwarzenberger P 2000 Propylthiouracil reduces xenograft tumor growth in an athymic nude mouse prostate cancer model. American Journal of the Medical Sciences 319 96-99. (https:// doi.org/10.1016/S0002-9629(15)40695-0)

Theodossiou C, Skrepnik N, Robert EG, Prasad C, Axelrad TW, Schapira DV \& Hunt JD 1999 Propylthiouracil-induced hypothyroidism reduces xenograft tumor growth in athymic nude mice. Cancer 86 1596-1601. (https://doi.org/10.1002/(SICI)10970142(19991015)86:8<1596::AID-CNCR30>3.0.CO;2-C)

Tomanek RJ \& Busch TL 1998 Coordinated capillary and myocardial growth in response to thyroxine treatment. Anatomical Record 251 44-49. (https://doi.org/10.1002/(SICI)10970185(199805)251:1<44::AID-AR8>3.0.CO;2-E)

Tseng FY, Lin WY, Li CI, Li TC, Lin CC \& Huang KC 2015 Subclinical hypothyroidism is associated with increased risk for cancer mortality in adult Taiwanese-a 10 years population-based cohort. PLOS ONE 10 e0122955. (https://doi.org/10.1371/journal. pone.0122955)

van Cruijsen H, Giaccone G \& Hoekman K 2005 Epidermal growth factor receptor and angiogenesis: opportunities for combined anticancer strategies. International Journal of Cancer 117 883-888. (https://doi.org/10.1002/ijc.21479)

Voronov E, Carmi Y \& Apte RN 2014 The role IL-1 in tumor-mediated angiogenesis. Frontiers in Physiology 5 114. (https://doi.org/10.3389/ fphys.2014.00114)

Weijl NI, Van der Harst D, Brand A, Kooy Y, Van Luxemburg S, Schroder J, Lentjes E, Van Rood JJ, Cleton FJ \& Osanto S 1993 Hypothyroidism during immunotherapy with interleukin-2 is associated with antithyroid antibodies and response to treatment. Journal of Clinical Oncology 11 1376-1383. (https://doi.org/10.1200/ JCO.1993.11.7.1376)

Wu SY, Green WL, Huang WS, Hays MT \& Chopra IJ 2005 Alternate pathways of thyroid hormone metabolism. Thyroid 15 943-958. (https://doi.org/10.1089/thy.2005.15.943)
Xie TX, Xia Z, Zhang N, Gong W \& Huang S 2010 Constitutive NF-kappaB activity regulates the expression of VEGF and IL-8 and tumor angiogenesis of human glioblastoma. Oncology Reports 23 725-732. (https://doi.org/10.3892/or_00000690)

Xiong JP, Stehle T, Diefenbach B, Zhang R, Dunker R, Scott DL, Joachimiak A, Goodman SL \& Arnaout MA 2001 Crystal structure of the extracellular segment of integrin alpha Vbeta3. Science 294 339-345. (https://doi.org/10.1126/science.1064535)

Yalcin M, Bharali DJ, Lansing L, Dyskin E, Mousa SS, Hercbergs A, Davis FB, Davis PJ \& Mousa SA 2009 Tetraidothyroacetic acid (tetrac) and tetrac nanoparticles inhibit growth of human renal cell carcinoma xenografts. Anticancer Research 29 3825-3831.

Yalcin M, Bharali DJ, Dyskin E, Dier E, Lansing L, Mousa SS, Davis FB, Davis PJ \& Mousa SA 2010a Tetraiodothyroacetic acid and tetraiodothyroacetic acid nanoparticle effectively inhibit the growth of human follicular thyroid cell carcinoma. Thyroid 20 281-286. (https://doi.org/10.1089/thy.2009.0249)

Yalcin M, Dyskin E, Lansing L, Bharali DJ, Mousa SS, Bridoux A, Hercbergs AH, Lin HY, Davis FB, Glinsky GV, et al. $2010 b$ Tetraiodothyroacetic acid (tetrac) and nanoparticulate tetrac arrest growth of medullary carcinoma of the thyroid. Journal of Clinical Endocrinology and Metabolism 95 1972-1980. (https://doi. org/10.1210/jc.2009-1926)

Yalcin M, Lin HY, Sudha T, Bharali DJ, Meng R, Tang HY, Davis FB, Stain SC, Davis PJ \& Mousa SA 2013 Response of human pancreatic cancer cell xenografts to tetraiodothyroacetic acid nanoparticles. Hormones and Cancer 4 176-185. (https://doi.org/10.1007/s12672013-0137-y)

Yeap BB, Alfonso H, Chubb SA, Walsh JP, Hankey GJ, Almeida OP \& Flicker L 2012 Higher free thyroxine levels are associated with frailty in older men: the Health in Men Study. Clinical Endocrinology 76 741-748. (https://doi.org/10.1111/j.1365-2265.2011.04290.x)

Yoshida T, Gong J, Xu Z, Wei Y \& Duh EJ 2012 Inhibition of pathological retinal angiogenesis by the integrin $\alpha v \beta 3$ antagonist tetraiodothyroacetic acid (tetrac). Experimental Eye Research 94 41-48. (https://doi.org/10.1016/j.exer.2011.11.003)

Zhang N, Jin W, Zhou S, Yang JD, Harmsen WS, Giama NH, Wongjarupong N, Heimbach JK, Watt KD, Malhi H, et al. 2018 Hypothyroidism is associated with worse outcomes of hepatocellular carcinoma patients after liver transplantation. Cancer Medicine $\mathbf{7}$ 5870-5878. (https://doi.org/10.1002/cam4.1797)

Received in final form 1 April 2019

Accepted 4 April 2019 (c) 2019 Society for Endocrinology Published by Bioscientifica Ltd. Printed in Great Britain 